\title{
Contagion in the CoCos Market? A Case Study of Two Stress Events*
}

\author{
Pierluigi Bologna, Arianna Miglietta, and Anatoli Segura \\ Banca d'Italia
}

The post-crisis regulatory framework has fostered the development of the market for contingent convertible bonds (CoCos). These instruments allow for loss absorption as a going concern, but their critics warn about their potential destabilizing effects in stress situations. We analyze the dynamics of the European CoCos market during two stress episodes that occurred in 2016 and were triggered by news on substantial unexpected losses faced by a European systemic bank. Our econometric approach aims at disentangling the fundamental contagion channels of the distress of such bank to the rest of the market from a potential CoCo-specific contagion channel. We find evidence of significant $\mathrm{CoCo}$-specific contagion in the first stress episode that could result from investors' reassessment of CoCos' riskiness or from uncertainty on their supervisory treatment. We do not find instead evidence of CoCospecific contagion in the second stress event, suggesting that as investors learn about the specificities of these instruments and their supervisory treatment, the CoCos market becomes more resilient.

JEL Codes: G14, G21, G28.

*Pierluigi would like to dedicate this work to Giovanni Abbate, a true mentor. The paper has benefited from useful discussions with and comments by Piergiorgio Alessandri, Antonio Bassanetti, Nicola Branzoli, Luisa Carpinelli, Francesco Corsello, Fabio Panetta, Tommaso Perez, Enrico Sette, Luigi Federico Signorini, Marco Taboga, participants of the Federal Reserve Board Division of Financial Stability and Policy Division seminar, and two anonymous referees. The views expressed are those of the authors and should not be attributed to the Bank of Italy or the Eurosystem. Author e-mails: pierluigi.bologna@bancaditalia.it (corresponding author); arianna.miglietta@bancaditalia.it; anatoli.seguravelez@bancaditalia.it. 


\section{Introduction}

In the aftermath of the global financial crisis, bank capital requirements have been significantly increased to enhance the resilience of the system. In a number of jurisdictions the new regulatory framework allows banks to satisfy part of the additional capital needs with contingent convertible bonds (CoCos). The CoCos are hybrid debt instruments that in adverse contingencies can be used to recapitalize the banks by writing down their principal or converting them into equity 1 Such a privileged regulatory treatment has spurred the growth of the CoCos market, with USD 521 billion of global issuances between the first issuance in 2009 and December 2015 (Avdjiev et al. 2020).

The rationale for the introduction of CoCos is related to their contingent debt-equity nature in two ways. First, they provide an equity injection when bank capital is needed and the bank is still a going concern, that is, when the bank is close to a given (regulatory) threshold but still above the regulatory minimums. Second, the debt feature, which prevails except in rare distress episodes, makes them appealing to both banks (as they carry a lower cost relative to equity) and fixed-income investors. Defendants of CoCos argue that these properties render these instruments optimal to increase the loss-absorption capacity of banks without imposing an excessive burden on bank profitability that could in turn negatively affect lending to the real economy (Duffie 2009; Squam Lake Working Group on Financial Regulation 2009; Flannery 2016; Vallee 2019). CoCos may also be beneficial by inducing timely recapitalization to avoid costly dilution of profits or loss of control (Pennacchi 2011; Calomiris and Herring 2013). However, these arguments are not shared by all academics and practitioners. Skeptics in fact argue that the double nature of CoCos introduces complexity and uncertainty that, should a $\mathrm{CoCo}$ be on the eve of conversion, may prove destabilizing for the issuer bank and could spill over to the rest of the market (Goodhart 2010; Allen 2012; Admati et al. 2013).

In this paper we shed light on the potential destabilizing effect of these securities by focusing on two stress periods experienced by

\footnotetext{
${ }^{1}$ Avdjiev, Kartasheva, and Bogdanova (2013) provide a description of the main design elements of CoCos.
} 
Deutsche Bank (DB) during 2016 that created significant concerns about the value of its EUR 4.6 billion CoCo issuances. The two stress periods, which started in January and September 2016, respectively, and lasted for a few weeks each, were initially triggered by announcements of substantial legal costs to be faced by DB. During the two events, the yield to maturity (YTM) of DB's senior bonds and CoCos peaked to historical maximums. The unfolding of these events was accompanied by great concerns from practitioners and commentators about DB's CoCos, and in particular about both the possibility that their coupons would not be paid and that the supervisory authority could mandate their conversion. The CoCos issued by the most important European banks also experienced severe tensions, especially during the January episode when their average YTM attained historical maximums (figure 2A). In that event, the YTM of the senior bonds issued by the same European banks also increased, although the level remained relatively contained. These dynamics could be the result of the contagion from a systemically important institution such as DB to other banks through "fundamental channels" stemming from, e.g., the network of interbank exposures or the possibility of fire sales. Yet, the "overreaction" of the CoCo market relative to the behavior of the senior bond market suggests that, in addition to fundamental distress propagation, the CoCo market could have been further destabilized by a broad reassessment of the riskiness of these instruments, ignited by the specific problems of DB's CoCos. Such a CoCo-specific contagion is precisely the type of concern raised by skeptics on these instruments and was frequently emphasized by commentators of these events. Our analysis of the two DB stress periods attempts at identifying whether or not there has been a CoCo-specific contagion beyond any fundamental distress propagation. By doing so, we investigate the potential unintended financial stability effects of a regulatory regime that encourages banks to issue CoCos.

In our empirical analysis we regress the logarithm of the daily YTM of the CoCos of European banks (excluding DB) on (i) the institutions' stock return, the YTM of their senior bonds, and the daily change of their expected default frequency (EDF); and on (ii) the YTM of DB's CoCos and its interaction with a dummy for each of the two events. The first set of controls aims at capturing the extent to which the CoCos YTM can be explained by variables 
related to the bank fundamentals such as its solvency risk (proxied by the YTM of the bank's senior bonds and by the EDF change) and its expected profitability (proxied by the bank's equity return). These variables allow us to control for the fundamental contagion from DB during the two distress episodes, and our specification thus captures how such contagion may have affected also CoCos prices. The second set of controls aims at capturing whether any interdependence between the Cocos of DB and those of other banks increased due to a Coco-specific contagion when DB was under distress.

Our results show across all the specifications used the existence of a CoCo-specific contagion channel in the propagation of the distress of DB to the rest of the European banks in the first of the two episodes, which supports CoCos skeptics' claim that these instruments might be a source of financial instability when negative shocks occur. Moreover, we also find that the behavior of the CoCos issued by riskier banks differs from those issued by safer institutions, which confirms also the existence of fundamental factors affecting the CoCo market dynamics. Yet, when comparing the CoCo-specific contagion between the two DB's events, we find that the channel is not at work anymore during the September episode. Such enhanced market stability could be consistent with investors' learning on the specificities of CoCos along time. The clarification by the European Banking Authority (2016b) and the European Central Bank (2016a) on the supervisory treatment of these instruments - in particular, with regard to the conditions that may call for the suspension of coupon payments - is also likely to have played a role in stabilizing the CoCos market during the second stress period of DB. All in all, the weakening of a CoCo-specific contagion mechanism suggests that the potential destabilizing role of these securities - claimed by CoCos skeptics - might be only transitory and/or could have been mitigated by regulators' intervention, but we are probably not yet able to say the last word.

The rest of the paper proceeds as follows. Section 2 briefly recalls the literature related to this paper. Section 3 describes the regulatory treatment of CoCos, the market development, and the two DB distress events. Section 4 discusses the two transmission channels of contagion: a fundamental and a CoCo-specific one. Section 5 describes the data. Section 6 presents the baseline empirical analysis. Section 7 provides some extensions of the baseline analysis. Section 8 
presents robustness exercises. Section 9 discusses the policy implications of our findings and concludes.

\section{Related Literature}

Our paper belongs to a growing literature on CoCos, starting with Flannery $(2005,2016)$. The theoretical contributions initially dealt with how design features affect the valuation of these instruments (e.g., Posner 2010; Pennacchi 2011; Glasserman and Nouri 2012). The possibility of multiple pricing equilibriums for CoCos with market trigger and the ensuing manipulation incentives by the different stakeholders was uncovered in Sundaresan and Wang (2015), and subsequent contributions have identified design features that eliminate such pricing multiplicity (Calomiris and Herring 2013; Pennacchi, Vermaelen, and Wolff 2014). In addition to structural models, proposals for pricing CoCos are based on equity and credit derivatives (for a review, see Wilkens and Bethke 2014) and on Mertontype models (e.g., Brigo, Garcia, and Pede 2015). Another strand of the theoretical literature has focused on how wealth transfers between the bank's stakeholders upon CoCo conversion may affect the ex ante risk-taking decisions of the bank in a counterproductive way (Hilscher and Raviv 2014; Flannery 2016; Martynova and Perotti 2018). Closer to the focus of our study, concerns that CoCos may not offer effective loss absorption in times of distress have been raised by practitioners, academics, and regulators (Pazarbasioglu et al. 2011; Delivorias 2016).

The empirical literature on CoCos is scarce and has not addressed potential contagion problems associated with the conversion of these instruments. Berg and Kaserer (2015) investigate the impact of CoCos' issuances on banks' risk-taking using a sample of CoCo bonds issued by European banks over the period 2009-13. The paper finds that some key design features of CoCos, such as a too high conversion price, lead the issuer bank to increase risk-taking. The literature has also shown that riskier banks are less likely to issue CoCos (Goncharenko, Ongena, and Rauf 2020). In a similar vein, Avdjiev et al. (2020) show that the propensity to issue CoCos is higher for better capitalized banks.

This paper is related also to the literature on contagion. The theoretical and empirical debate on what contagion means is far from conclusive, as emphasized by Pericoli and Sbracia (2003) and Forbes 
(2012). We interpret an increase in the co-movement of CoCo prices after controlling for variations in the banks' fundamentals as evidence of CoCo-specific contagion. The notion of contagion as a transmission of shocks in excess of what can be explained by fundamentals is discussed in Claessens, Dornbusch, and Park (2001), Forbes and Rigobon (2002), and Forbes (2012), and has been adopted in the analysis by, e.g., Calvo and Mendoza (2000), Bekaert, Harvey, and $\mathrm{Ng}$ (2005), and Bekaert et al. (2014).

\section{The CoCos Market and the Two Deutsche Bank Stress Events}

\subsection{CoCos Market Developments and Regulatory Treatment}

The issuance of CoCos by European banks has grown steadily since the adoption of Basel III and its introduction in Europe by means of the Capital Requirements Directive IV (CRD IV) and the Capital Requirements Regulation (CRR).

Under Basel III, hybrid capital instruments, such as CoCos, are designed to absorb losses while the bank is still a going concern and are classified as additional tier 1 (AT1) capital. To qualify as AT1, CoCos must have, like common equity, a perpetual maturity and noncumulative coupons, payable at the discretion of the issuer. They also need a loss-absorption trigger which allows the principal to be written down or converted to common equity without this event constituting a default of the issuer (Basel Committee for Banking Supervision 2011a). The trigger is activated when the common equity tier 1 (CET1) capital ratio of the bank falls below a CET1 ratio threshold that has to be set no lower than 5.125 percent (Basel Committee for Banking Supervision 2011b). These features should help to strengthen banks' capital position at a time when raising equity would otherwise be difficult 2 Furthermore, allowing the issuer to miss coupon payments can reduce pressure on liquidity. Finally, in a resolution process, CoCos are senior only to common equity.

\footnotetext{
${ }^{2}$ In addition to the automatic triggers, supervisory authorities can mandate the conversion or the write-down of CoCos by discretionally activating the point of nonviability (PONV) triggers, if they believe that such action is necessary to prevent the bank from becoming insolvent (Delivorias 2016).
} 


\section{Figure 1. The Market of Contingent Convertible Bonds (EUR billion)}

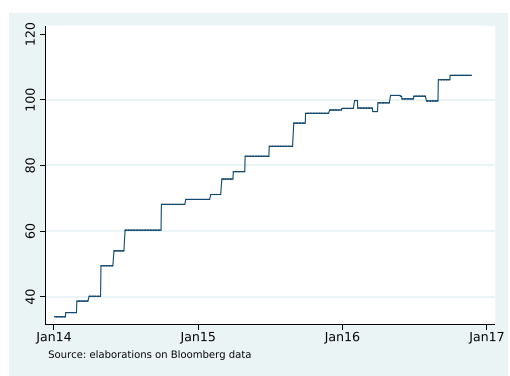

(a) European banks CoCos outstanding issuances (January 2014 - November 2016)

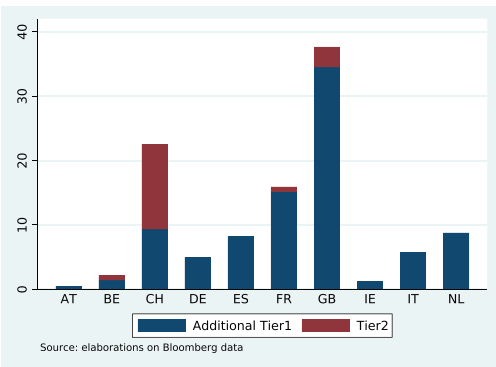

(b) European banks CoCos outstanding by country and Basel III capital category (November 2016)

In the European Union (EU), the CRD IV and the CRR make the coupon distribution on CoCos conditional on the banks' meeting the combined buffer requirement (CBR) 3 Should a bank not meet its CBR, the amount of payouts it can make in the form of dividends and coupon payments on AT1 instruments would be limited by the institution's maximum distributable amount (MDA) (CRD IV, Article 141).

The favorable regulatory treatment of CoCos - combined with banks' need to strengthen their capital position during difficult market conditions for equity issuances - has spurred the development of the CoCos market in Europe 4 Based on the Bank of America Merrill Lynch Contingent Capital Index (BAMLCCI), European banks have almost tripled their CoCo issuances, with the outstanding volume rising from EUR 33.8 billion to EUR 107.4 billion between January 2014 and November 2016 (figure 1A).

The regulatory incentive in the growth of CoCos is confirmed by the fact that the vast majority of issuances qualify as AT1 capital, with only a small fraction of the total eligible as tier 2 capital

${ }^{3}$ According to Article 128 of the CRD IV, the CBR is the sum of the capital conservation buffer requirement and, when applicable, the countercyclical capital buffer requirement, the G-SII (global systemically important institutions) and O-SII (other systemically important institutions) buffer requirements, and the systemic risk buffer requirement.

${ }^{4}$ The need to strengthen capital adequacy has been felt by banks in particular during the preparation of the entry into force of the Single Supervisory Mechanism, which had as a milestone the completion of Asset Quality Review in October 2014. 
(figure 1B). It is also worth highlighting that the tier 2 CoCos have mostly been issued in the early days of the newborn market well before the approval of Basel III 5

Despite this strong growth, toward the end of 2015, uncertainties emerged in the interpretation of the legal framework for the computation of the MDA trigger, i.e., the level of the capital requirements below which a bank would need to calculate the MDA and restrict its payouts, including those on AT1 instruments. In particular, it was unclear whether the CBR would come in addition to the 8 percent pillar 1 minimum requirements only, or in addition to both the pillar 1 and pillar 2 requirements. To clarify this issue, in December 2015 the European Banking Authority (2015) published an opinion in which it reaffirmed that both pillar 1 and pillar 2 requirements should be below the CBR when determining the MDA trigger. It was also recognized that, given the importance of the MDA trigger to investors in AT1 instruments, there should be full disclosure of the pillar 2 requirements. In early 2016, the European Central Bank (2016b) endorsed the EBA opinion. Notwithstanding such a clarification, uncertainties yet remained, this time due to the possibility that some banks could have breached the MDA trigger not because of actual losses but rather because of potential losses arising from the adverse scenario of the supervisory stress test, which would have been carried out over the following months.

Issuances of CoCos abruptly halted in early 2016, contemporaneously to the first DB stress period analyzed in this paper.

\subsection{The Two Deutsche Bank Stress Events}

In this section we discuss in more detail each of the two distress episodes experienced by DB in 2016 .

\subsubsection{Event 1}

The first event took place at the beginning of 2016 after the announcement of negative earnings expectations for 2015, which came as a surprise for market participants.

\footnotetext{
${ }^{5}$ The first CoCo was issued by Lloyds Banking Group in November 2009.
} 


\section{Figure 2. The CoCos and the Senior Bond Markets during Deutsche Bank's CoCos Distress (yield to maturity; January 2, $2015=100)$}

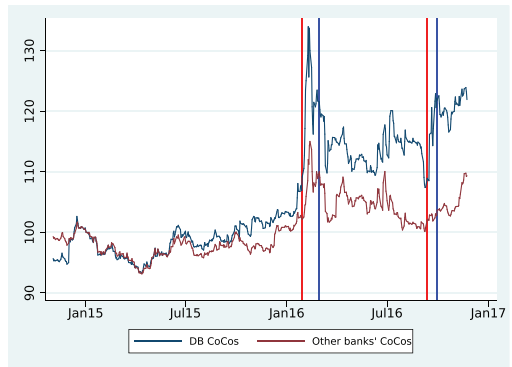

(a) The CoCos market

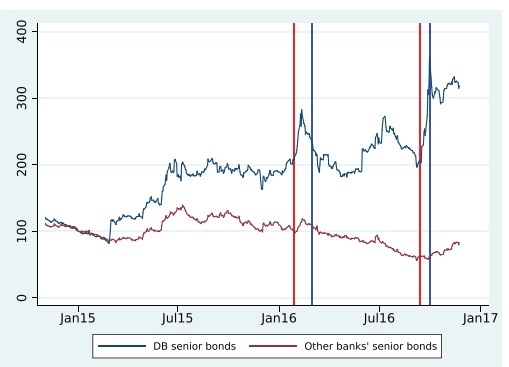

(b) The senior bonds market

On January 20, 2016 DB announced that it expected an extraordinary high net loss of about EUR 6.7 billion for 2015, due to unanticipated very high litigation charges and restructuring costs and to cyclical market conditions (which led in particular to a fall in revenues from the bank securities trading unit). When the news was published, DB's debt securities reacted negatively (figures $2 \mathrm{~A}$ and $2 \mathrm{~B}$ ). The situation worsened a few days later on January 28 when the chief executive officer (CEO) of Deutsche Bank, John Cryan, addressed a message to the bank's employees. In particular, he clarified that the yearly losses for 2015 (revised by then to EUR 6.8 billion) had been driven mainly by regulatory and litigation provisions (EUR 5.2 billion) and impairments on goodwill and other intangible assets (EUR 5.8 billion) while, differently from the previous announcement, little emphasis was given to the market conditions. The news about the loss, coupled with the uncertainty about the bank's capital position relative to the MDA trigger, raised dramatically the concerns on the capability of DB to meet the forthcoming payments on its CoCos (Glover 2016). This in turn led the bank to take a number of initiatives to restore market confidence: on February 8, 2016, in a press release and in a message to the bank employees by the chief financial officer (CFO) of Deutsche Bank, Marcus Schenck, the bank's availability of cash to make the upcoming payments due on the CoCos was reaffirmed 6 Then on the

http://www.db.com/newsroom_news/2016/ir/deutsche-bank-publishesupdated-information-about-at1-payment-capacity-en-11391.htm and 
following day another message to the employees was sent by the CEO, who claimed that "Deutsche Bank remains absolutely rocksolid." 7 On February 12, 2016, the CFO announced a tender offer to buy back in the market some of the bank senior unsecured debt, "taking advantage of market conditions to repurchase this debt, lowering its debt burden at attractive prices" and with "no impact on the bank's capacity to service coupons on its AT1 capital." 8 The buyback operation was clearly aimed at proving the soundness of the bank to the markets. On February 29, 2016, the CFO announced the success of the operation, which was welcomed by the market 9 After that date, conditions began to improve. The stabilization of the CoCos market might have also benefited from the recognition by the ECB, in February 2016, of the need to reduce uncertainty on the supervisory treatment of these instruments, and, in particular, on the conditions that would lead to the suspension of coupon payments. After long debate, the ECB announced on July 29, 2016, changes in the methodology to calculate the banks' MDA trigger that would effectively reduce the likelihood that banks would not be allowed to make CoCo coupon payments (see section 9 for more details).

Before the described event, the price of DB's CoCos was essentially stable. However, at the beginning of 2016 the YTM started to rise with a sudden spike of almost 200 basis points (figure 2A). In particular, the YTM jumped from an average of around 660670 basis points in mid-January 2016 to more than 850 basis points in mid-February. We set the start date of the first distress episode on January 28 when, after the profitability announcement and the first message by the CEO of DB, the YTM of DB's CoCos spiked by more than 100 basis points. We set the end date on February 29

\begin{tabular}{l}
\hline http://www.db.com/newsroom_news/2016/ghp/a-message-from-marcus- \\
\hline schenck-deutsche-bank-s-additional-tier-1-at1-capital-en-11386.htm/ \\
Thttp://www.db.com/newsroom_news/2016/ghp/a-message-from-john-cryan- \\
to-deutsche-bank-employees-0902-en-11392.htm/ \\
9http://www.db.com/newsroom_news/2016/ghp/a-message-from-marcus- \\
schenck-deutsche-bank-announces-a-public-tender-offer-to-buy-back-debt-en- \\
11399.htm. \\
[http://www.db.com/newsroom_news/2016/medien/deutsche-bank- \\
announces-results-of-public-tender-offer-for-us-dollar-bonds-as-of-early-tender- \\
date-en-11494.htm.
\end{tabular}


when, after the announcement of the successful completion of a debt buyback, the YTM substantially declined 10

\subsubsection{Event 2}

The second distress event of DB started on September 12, 2016 when a number of articles in the press announced that the bank had received a USD 14 billion fine by the U.S. Justice Department. The news came after a series of other bad news that involved the bank over the summer 11 putting the institution under serious investors' scrutiny that was further exacerbated by the reports that the German government wouldn't help the ailing bank (Donahue 2016). Both DB's CoCos and senior bonds yields took a hit, with the senior bonds exceeding the peak observed in February 2016 (figures 2A and 2B).

The rise in DB senior bonds and CoCos YTM started therefore on September 12, with an average increase on all issues by about 10 basis points in one day for both types of securities. Then other large one-day increases followed, particularly on September 16 when the news of the fine was confirmed - with the average YTM of DB senior bonds and CoCos increasing by 36 and 49 basis points, respectively (Davies 2016 and Strasburg 2016) - and on September 26 when the rumors about the government unwillingness to help the bank spread (Donahue 2016) - with the average YTM of DB senior bonds and CoCos increasing by 22 and 29 basis points, respectively. A number of interventions at the end of September contributed to the recovery from this distress. In particular, on September 30 the CEO of DB reassured the market and the bank employees about the soundness

\footnotetext{
${ }^{10}$ The results presented in section 6.3 , section 7 , and section 8 are robust to setting the beginning of the distress event to January 20, i.e., when DB announced for the first time the negative results.

${ }^{11}$ The most relevant are the following: (i) in June the International Monetary Fund (IMF) stated that DB "appears to be the most important net contributor to systemic risks in the global banking system" (IMF 2016); (ii) also in June, the U.S. subsidiary of DB failed for the second consecutive year the stress test performed by the Federal Reserve, as the regulator rejected the bank capital plan (Federal Reserve Board 2016); (iii) in July, the rating agency Standard \& Poor's lowered its outlook on the bank's rating; (iv) again in July, the bank passed the EU-wide stress test by a tight margin (EBA 2016a); and (v) in August the bank was removed from the Stoxx 50 index.
} 
of the bank's financial conditions 12 on the same day, Eurogroup President Jeroen Dijsselbloem stated that the USD 14 billion fine to $\mathrm{DB}$ was excessive 13 and unconfirmed reports claimed that the bank was about to agree on a reduction of the fine with the U.S. Department of Justice 14 Taking this information into account, in our empirical analysis we set September 12 as the start date of the second distress event, and September 30 as the end date.

\section{The Transmission Channels: Fundamental and CoCo-Specific Contagion}

The sequence of news in January and September 2016 led to mounting concerns on the ability of DB to pay the coupons on its CoCos or even of a possible write-down of their notional value. This information also increased the insolvency risk of DB, as shown by the large increases in the YTM of its senior debt. During both periods stock prices declined significantly, reflecting mounting investors' concerns on DB's profitability outlook. As exhibited in figures 2A and $2 \mathrm{~B}$, the rest of the European banking sector experienced also some distress: the YTM of the senior bonds and of the CoCos of European banks increased (and their stock prices fell). Such a comovement may be the result of a propagation mechanism based on two contagion channels: a fundamental one and a CoCo-specific one.

First, DB is a global systemically important institution whose financial difficulties may spill over to other institutions. This could result from the losses that DB's counterparties would suffer directly in case of its insolvency, and indirectly from the exposure to other institutions through a loss cascade propagated by the network of interbank exposures. The distress of a systemic intermediary with important trading activities such as DB may also lead to substantial fire sales that would depress asset values and negatively affect the capitalization of banks with similar assets in their trading portfolio.

\footnotetext{
$\sqrt[12]{\text { http://www.db.com/newsroom_news/2016/medien/media-reports-on- }}$ deutsche-bank-a-message-to-employees-from-john-cryan-en-11702.htm

${ }^{13}$ http://euobserver.com/tickers/135321.

${ }^{14}$ The rumors were indeed confirmed by the facts, as an agreement had been found in December when the fine was almost halved to USD 7.2 billion.
} 
Negative spillovers on the economy could also arise due to secondround general equilibrium effects following the failure of a systemic institution. For example, it could reduce or make more costly the access to credit for banks' customers, which may as a response cut down investment or hiring; this in turn could depress the rest of the economy and, through this channel, the quality of other banks' assets. We refer to all these propagation mechanisms as "fundamental." They may explain all or part of the price evolution of banks' liabilities, including their CoCo instruments.

Second, both in January and September 2016, the news that DB may face substantial losses immediately brought the attention to the institutions' capability to satisfy the coupon payments of its CoCos and to the possibility that supervisors would prohibit the bank from paying their coupons. More generally these events led to statements by practitioners and commentators alike on a broad reassessment of the riskiness of CoCos, and to concerns that their design and their debtlike features during normal times could have led investors to misunderstand these instruments. During these stress episodes, investors' uncertainty about CoCos could have led to adverse price dynamics extending from DB's CoCos to the CoCos issued by other institutions, well beyond what would be explained by fundamental factors (e.g., banks' credit risk, profitability, etc.) We refer to such a propagation as "CoCo-specific contagion."

The European banking sector was affected by the difficulties of DB in the two stress episodes, albeit to a different extent. While the severity of the distress of DB, as proxied by the change in the YTM of its senior bonds, was of a similar intensity in the two periods, the magnitude of the movements in the other European banks' senior bonds and CoCos YTM was significantly smaller in the second event.

In the first event, the yield of the senior bonds of the major European banks experienced a short-lived increase, within the range of variation observed in the previous 12 months. This suggests apossibly weak - fundamental contagion from DB to the other major European banks. In contrast, the European banks' CoCos yield hit an all-time high, which constitutes suggestive evidence of a CoCospecific contagion.

In the second event, instead, the senior bond yield of the European banks remained essentially unchanged, which we can interpret as evidence of a very weak or even lack of fundamental contagion. 
The CoCos yields increased somewhat, although their maximum level remained well below that attained in the first event. The lower magnitude of the movements in the CoCos market during the second stress episode relative to the first could be the result of a lower fundamental contagion and/or a lower CoCo-specific contagion. A less intense contagion through the Coco-specific channel could be due to an ameliorated understanding by investors of the mechanisms and risks underlying these instruments following the January episode. Furthermore, the actions taken by the ECB during the summer, namely the reduction of the capital ratio below which coupon payments would not be allowed by regulators, could have contributed as well to mitigate volatility transmission through this channel.

In the next sections we investigate whether the described anecdotal evidence on both a fundamental and a CoCo-specific contagion, as well as their relative magnitude across the two events, can be confirmed by the empirical analysis.

\section{Data}

The main data set used is provided by the BAMLCCI. This index tracks on a daily basis the performance of contingent capital bonds publicly issued in the major markets. In addition to closing market data (e.g., price, YTM, spread, and duration), information from this source includes a large number of variables at International Securities Identification Number (ISIN) level (e.g., maturity date, rating, amount outstanding, issuance currency, and whether the instrument is classified as AT1 or T2 capital). Further information on CoCos' main contractual characteristics is extracted from Bloomberg, including for instance the loss-absorption mechanisms (principal write-down/equity conversion), the type of write-down (temporary, permanent), the underlying trigger variable (e.g., tier 1 ratio, CET1), and the trigger level. Data at issuer level are collected from various sources: (i) senior unsecured bonds are from the Merrill Lynch index ER00; (ii) daily (closing) equity prices are from Bloomberg; (iii) five years expected default frequency (EDF) probability are from Moody's Analytics, and (iv) balance sheet data are 
Table 1. Summary Statistics of CoCos Issuances

\begin{tabular}{|l|c|c|c|c|}
\hline & $\begin{array}{c}\text { No. of Daily } \\
\text { Observations }\end{array}$ & $\begin{array}{c}\text { No. of } \\
\text { Issues }\end{array}$ & $\begin{array}{c}\text { Volume } \\
\text { No. of } \\
\text { Issuers }\end{array}$ & $\begin{array}{c}\text { Outstanding } \\
\text { (EUR Billion, } \\
\text { Nov. 2016) }\end{array}$ \\
\hline Austria & 105 & 1 & 1 & 0.5 \\
Belgium & 1,276 & 2 & 1 & 2.1 \\
France & 7,036 & 15 & 3 & 15.9 \\
Germany & 2,930 & 5 & 2 & 5.0 \\
Italy & 2,848 & 6 & 2 & 4.3 \\
The Netherlands & 1,070 & 3 & 2 & 3.1 \\
Spain & 4,189 & 9 & 3 & 10.5 \\
Switzerland & 8,168 & 16 & 2 & 21.7 \\
United Kingdom & 13,902 & 29 & 4 & 32.3 \\
Total & 41,524 & 86 & 20 & 95.4 \\
\hline
\end{tabular}

from S\&P Global Market Intelligence 15 The securities in our sample are issued by European banks between June 2014 and November 201616 Overall we have a sample of 86 CoCos issued by 20 banks located in nine European countries (table 1) 17 The U.K. and the Swiss banking systems are the most represented in our sample, with both the largest number of issuances (29 and 16 issues, respectively) and the highest volume outstanding (about EUR 32 billion and EUR 22 billion, respectively, as of November 2016). Securities in the data set are denominated in EUR, USD, and GBP. Tables 2, 3, and 4

\footnotetext{
${ }^{15}$ Matching the original data set with stock prices, EDF, and balance sheet information has led to a reduction of the original panel of banks from the BAMLCCI index, which originally included data on 98 CoCos and 28 issuers located in 10 countries.

${ }^{16}$ The empirical specification includes the daily average YTM of the CoCos issued by DB (see section 6). Regressions therefore start in June 2014 when a CoCo issued by DB enters the BAMLCCI.

${ }^{17}$ Information on issuers is aggregated at group level if the holding bank is represented in our sample. The banks included are the following: Erste Group (Austria), KBC Bank (Belgium), Societe Generale, Credit Agricole, and BNP Paribas (France), Aareal Bank and Deutsche Bank (Germany), Intesa SanPaolo and Unicredit (Italy), ABN Amro and Ing Group (the Netherlands), Banco Bilbao Vizacaya Argentaria, Bankinter, and Banco Santander (Spain), Credit Suisse and UBS (Switzerland), Barclays Plc., HSBC, Lloyds Banking Group, and Royal Bank of Scotland (United Kingdom).
} 


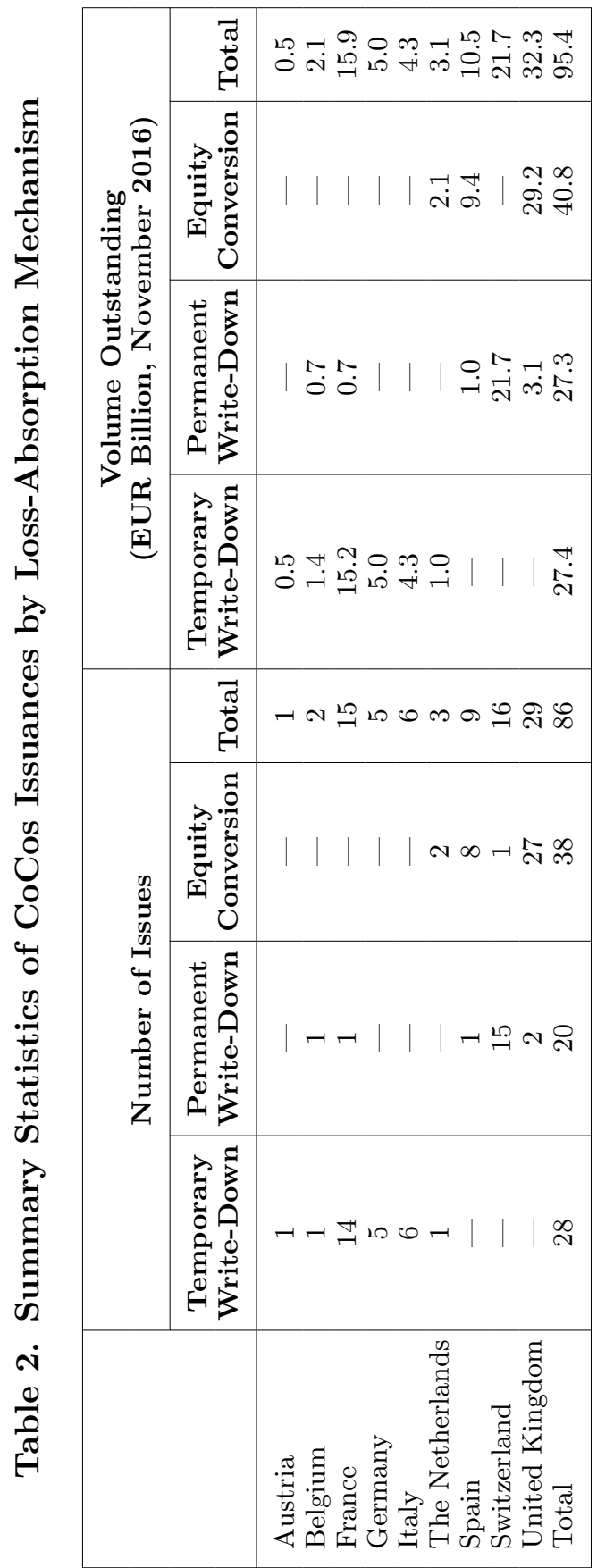




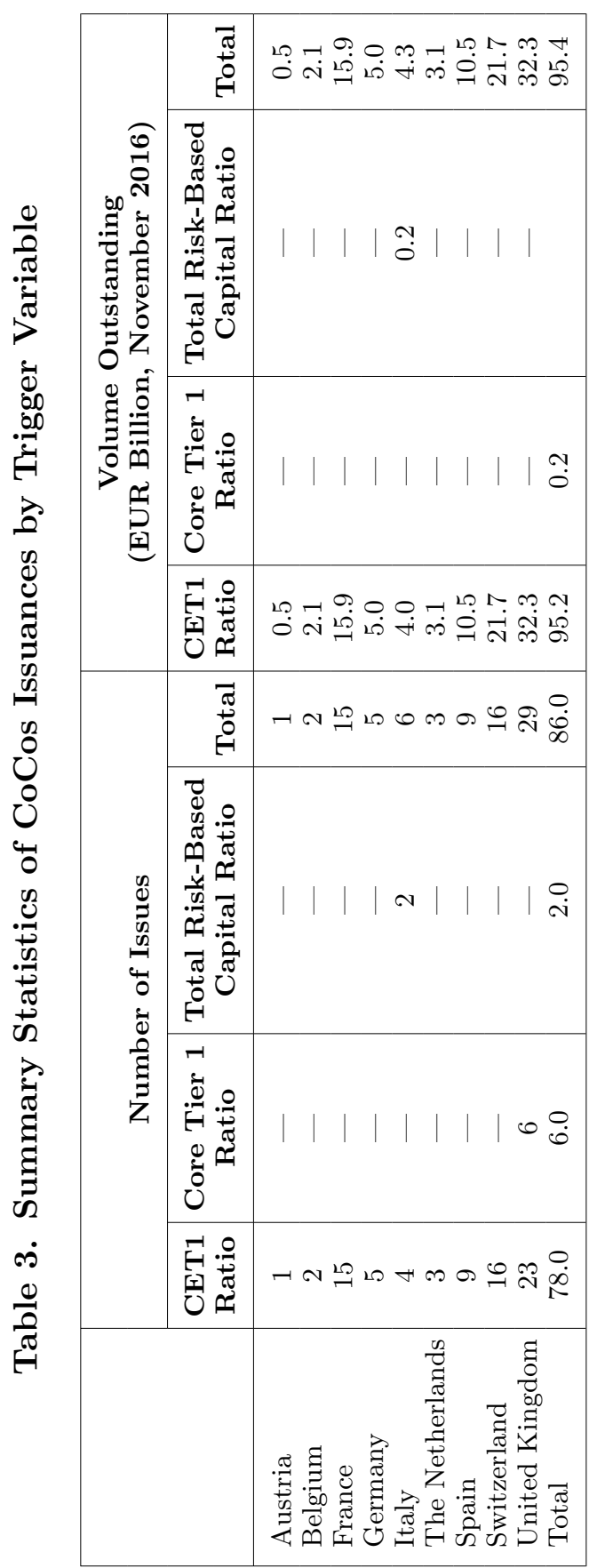




\section{Table 4. Summary Statistics of CoCos Issuances by Trigger Level}

\begin{tabular}{|l|c|c|c|c|c|}
\hline \multirow{2}{*}{} & \multicolumn{5}{c|}{ Number of Issues } \\
\cline { 2 - 6 } & \multicolumn{3}{|c|}{$\begin{array}{c}\text { Low } \\
\text { Trigger }\end{array}$} & $\begin{array}{c}\text { High } \\
\text { Trigger }\end{array}$ \\
\cline { 2 - 5 } & $\mathbf{5 \%}$ & $\mathbf{5 . 1 2 5 \%}$ & $\mathbf{6 \%}$ & $\mathbf{7 \%}$ & Total \\
\hline Austria & - & 1 & - & - & 1 \\
Belgium & - & 1 & - & 1 & 2 \\
France & - & 14 & - & 1 & 15 \\
Germany & - & 4 & - & 1 & 5 \\
Italy & - & 4 & 2 & - & 6 \\
The Netherlands & - & 1 & - & 2 & 3 \\
Spain & - & 8 & - & 1 & 9 \\
Switzerland & 7 & 4 & - & 5 & 16 \\
United Kingdom & 6 & - & - & 23 & 29 \\
Total & 13 & 37 & 2 & 34 & 86 \\
\hline $\begin{array}{l}\text { Notes: We follow Avdjiev, Kartasheva, and Bogdanova (2013) and define a high } \\
\text { (low) trigger CoCo bond as one having a trigger level above (below) } 6 \text { percent of the }\end{array}$ \\
ratio between common equity tier 1 capital and risk-weighted assets (CET1/RWA). \\
\hline
\end{tabular}

present detailed summary statistics regarding the main contractual features for the selected sample of CoCos. Statistics by country of the average daily YTM of the CoCos and of the senior bonds as well as of the average returns of equity prices, of average EDF change, and of distance to trigger are provided in table 5 .

\section{Empirical Analysis}

\subsection{Setup}

In order to disentangle fundamental from CoCo-specific contagion, we define the following baseline model:

$$
\begin{aligned}
\log \left(Y_{i, j, t}\right)= & \alpha_{i, j}+\beta \log \left(Y_{i, j, t-1}\right)+\sum_{k=1,3} \gamma_{k} X_{k, j, t}+\eta C_{i, j, t}+\delta Y_{D B, t} \\
& +\sum_{s=1,2} \varrho_{s} \text { Dummy }_{s, t} \\
& +\sum_{s=1,2} \varphi_{s} Y_{D B, t} \text { Dummy }_{s, t}+\theta Z_{i, j, t}+\varepsilon_{i, j, t} .
\end{aligned}
$$




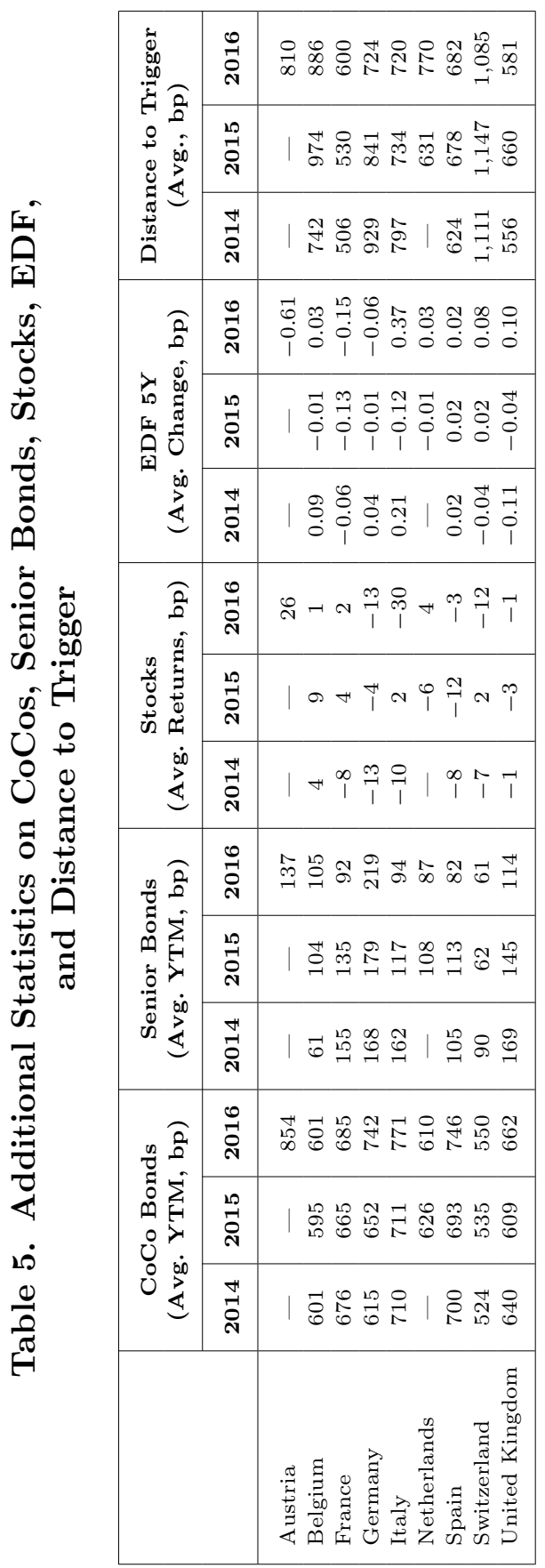


The log-linear specification of the model helps to control for the possible nonlinearity that exists in the relations between senior bonds and CoCos, and between equity prices and CoCos, which can be especially important when banks' financial position is eroded and the pricing of their CoCos becomes more information sensitive. The dependent variable, $\log \left(Y_{i, j, t}\right)$, is the natural logarithm of the daily YTM of CoCo $i$, issued by a European bank $j$ other than DB, at time $t$. We include as a regressor one lag of the dependent variable, $\log \left(Y_{i, j, t-1}\right)$, to account for serial correlation in yields. The bankspecific controls $X_{k, j, t}$, with $k=1,2,3$, consist of the daily average YTM of the senior bonds $(k=1)$ issued by bank $j$, of the daily stock return $(k=2)$ of bank $j$, and of the daily change in the bank EDF five years ahead, all at time $t$. By using these controls, we aim to capture the variation in the CoCos YTM that can be explained by the changes in a bank's fundamental conditions such as its solvency (proxied by the YTM of the bank's senior bonds and the bank EDF) and its expected profitability (proxied by the bank's equity return). To the extent that there is a fundamental contagion from DB to the other banks' CoCos YTM during the two distress episodes, it should be reflected by these variables. The CoCo and bank-specific variable $C_{i, j, t}$ is the distance to trigger, namely the difference between the bank $j$ capital ratio and the CoCo $i$ trigger level, measured at time $t$. As a measure of a CoCo's risk, we expect it to matter for its pricing. This variable is updated quarterly (the regulatory reporting frequency for bank capital) and the information becomes available with a lag to the reference date.

The variable $Y_{D B, t}$ is the daily average YTM of the CoCos issued by $\mathrm{DB}$ which we use to control for the possible co-movement between the CoCos of DB and those of the other banks 18 In particular, the coefficient of $Y_{D B, t}$ in the baseline regression would capture the average interdependence in the YTM of CoCos, along all the sample and time span considered, which could result from unobserved variables that affect the pricing of all CoCos, but not that of the other bank securities.

We interact $Y_{D B, t}$ with the dummy variables Dummy Dut $_{\text {, with }}$ $s=1,2$, which identify the two DB stress periods as previously

\footnotetext{
${ }^{18}$ The results in the paper are robust to an alternative specification with the natural logarithm of the YTM of DB's CoCos instead of the YTM of DB's CoCos.
} 
defined. The coefficients of the interactions aim to capture whether there has been a change in the interdependence between the CoCo of DB and those of other banks when DB was under distress (and investors spotted the riskiness of its CoCos).

Finally, $Z_{i}$ is a vector of CoCo-specific variables that includes the type of action upon conversion (principal write-down or equity conversion), the type of write-down (temporary or permanent), the regulatory treatment of the instrument (AT1 or tier 2), the trigger level (high or low 19 ), the possibility for the supervisory authority to suspend coupon payments, and the size of the issue.

We use the baseline regression to test the following hypothesis:

Hypothesis 1. Existence of CoCo-specific contagion in the first and/or the second stress period.

We say that there is evidence of CoCo-specific contagion in the stress period $s$ if the coefficient of $Y_{D B, t}$ Dummys,t is statistically significant and positive. Our definition of contagion is consistent with that of Forbes and Rigobon (2002) that considers contagion to be an increase in cross-dependence across markets during crises periods. Note that since we control for the banks' equity returns, senior unsecured debt YTM, and EDF change, the potential fundamental contagion from DB to the other banks' CoCos should be transmitted through the effect of DB's distress on these variables.

\subsection{Estimation}

Equation (1) is first estimated using a generalized least squares (GLS) estimator with random effects, to control for the issue-specific characteristics of the CoCos. We estimate the model by clustering standard errors by a "bank*time" variable and by allowing for intragroup correlation (i.e., relaxing the usual assumption that the observations are independent), since the null hypothesis of no serial correlation in the residuals is rejected by the Wald test discussed

\footnotetext{
${ }^{19}$ We follow Avdjiev, Kartasheva, and Bogdanova (2013) and define a high (low) trigger CoCo bond as one having a trigger level above (below) 6 percent of the ratio between common equity tier 1 capital and risk-weighted assets (CET1/RWA). The results of the analysis do not change if we set the threshold at 5.125 percent, the regulatory minimum for a CoCo to qualify as AT1.
} 
in Wooldridge (2002) and for which Drukker (2003) shows the good size and power properties.

In addition, as the likelihood-ratio test shows that there is heteroskedasticity across groups, we also run a feasible GLS (FGLS) estimation with heteroskedastic error structure across panels and a panel-specific $\mathrm{AR}(1)$ process within panels.

The time dimension of our panel is large enough (638 days) and hence we a priori expect the dynamic panel bias of GLS and FGLS estimations to be small. We nonetheless check the results against the generalized method of moments estimator proposed by Blundell and Bond (1998), also known as system GMM. The latter framework accounts for endogeneity, controls for unobserved heterogeneity, and deals with the biases and inconsistencies typical of least-square estimations, provided that the model is not subject to serial correlation of order two and the instruments used are valid. We estimate the system GMM with a two-step estimator robust to panel-specific autocorrelation and heteroskedasticity.

\subsection{Results}

The results from the estimation of equation (1) are shown in table 6 , with the GLS estimation reported in column 1, the FGLS in column 2, and the system GMM in column 3. They show, as expected, that the CoCo YTM is inversely related with the bank stock returns, as shown by the significance of the stock return variable (columns 1 and 2), and that it positively co-moves with the senior bonds YTM (columns 1 and 2) and with the EDF change (columns 1 and 2). The negative sign of the coefficient of the distance to trigger (columns 1 and 2) indicates as well that the CoCos issued by the riskier banks, i.e., banks with a relatively lower capital ratio, are priced at a higher YTM. These findings show that there is a close relationship between the banks' fundamental conditions and the pricing of their CoCos. Any effect of the two DB events on the other banks' CoCos resulting from the fundamental contagion channel previously described should therefore be captured by the significance of the senior bond, stock return, and EDF variables. This is less the case for the distance to trigger, which - although being a significant driver of CoCos YTM - has a much lower frequency (quarterly instead of daily as in the case of the other variables) and is observed with a long lag. 
Table 6. Fundamental and CoCo-Specific Dependence of CoCos YTM during DB Events

\begin{tabular}{|c|c|c|c|}
\hline Variables & $\begin{array}{c}\text { GLS RE } \\
\text { (1) }\end{array}$ & $\begin{array}{l}\text { FGLS } \\
\quad(2)\end{array}$ & $\begin{array}{c}\text { System } \\
\text { GMM } \\
(3)\end{array}$ \\
\hline Lag CoCo YTM & $\begin{array}{c}0.994^{* * *} \\
(0.002)\end{array}$ & $\begin{array}{c}0.998^{* * *} \\
(0.000)\end{array}$ & $\begin{array}{c}0.993^{* * *} \\
(0.002)\end{array}$ \\
\hline Senior Bond YTM & $\begin{array}{l}0.166^{* *} \\
(0.075)\end{array}$ & $\begin{array}{c}0.039^{* * *} \\
(0.012)\end{array}$ & $\begin{array}{c}0.052 \\
(0.175)\end{array}$ \\
\hline Stock Return & $\begin{array}{c}-0.094^{* * *} \\
(0.012)\end{array}$ & $\begin{array}{c}-0.092^{* * *} \\
(0.002)\end{array}$ & $\begin{array}{l}-0.077 \\
(0.091)\end{array}$ \\
\hline EDF Change & $\begin{array}{c}1.223^{* * *} \\
(0.319)\end{array}$ & $\begin{array}{c}0.402^{* * *} \\
(0.118)\end{array}$ & $\begin{array}{c}6.138 \\
(5.123)\end{array}$ \\
\hline Distance to Trigger & $\begin{array}{c}-0.024^{* *} \\
(0.012)\end{array}$ & $\begin{array}{c}-0.009^{* * *} \\
(0.003)\end{array}$ & $\begin{array}{l}-0.013 \\
(0.010)\end{array}$ \\
\hline CoCo DB & $\begin{array}{c}0.039 \\
(0.029)\end{array}$ & $\begin{array}{c}0.052^{* * *} \\
(0.008)\end{array}$ & $\begin{array}{l}-0.299 \\
(0.225)\end{array}$ \\
\hline CoCo DB $\times$ Event1 & $\begin{array}{l}1.227^{* * *} \\
(0.205)\end{array}$ & $\begin{array}{c}1.414^{* * *} \\
(0.048)\end{array}$ & $\begin{array}{l}4.085^{* *} \\
(1.809)\end{array}$ \\
\hline CoCo DB $\times$ Event 2 & $\begin{array}{l}-0.050 \\
(0.124)\end{array}$ & $\begin{array}{l}-0.093 \\
(0.082)\end{array}$ & $\begin{array}{l}-0.026 \\
(0.110)\end{array}$ \\
\hline Event1 & $\begin{array}{c}-0.095^{* * *} \\
(0.015)\end{array}$ & $\begin{array}{c}-0.108^{* * *} \\
(0.004)\end{array}$ & $\begin{array}{c}-0.315^{* *} \\
(0.139)\end{array}$ \\
\hline $\begin{array}{l}\text { Event2 } \\
\text { CoCos Characteristics: }\end{array}$ & $\begin{array}{c}0.005 \\
(0.009)\end{array}$ & $\begin{array}{c}0.007 \\
(0.006)\end{array}$ & $\begin{array}{c}0.004 \\
(0.008)\end{array}$ \\
\hline Subordination Type & $\begin{array}{c}-0.004^{*} \\
(0.002)\end{array}$ & $\begin{array}{c}-0.001^{* * *} \\
(0.000)\end{array}$ & $\begin{array}{c}-0.005^{* * *} \\
(0.001)\end{array}$ \\
\hline Equity Conversion & $\begin{array}{l}-0.000 \\
(0.001)\end{array}$ & $\begin{array}{c}0.000 \\
(0.000)\end{array}$ & $\begin{array}{l}-0.001 \\
(0.001)\end{array}$ \\
\hline Permanent Write-Down & $\begin{array}{l}0.002^{*} \\
(0.001)\end{array}$ & $\begin{array}{l}0.000^{* *} \\
(0.000)\end{array}$ & $\begin{array}{c}0.002 \\
(0.001)\end{array}$ \\
\hline Cancellation by Regulators & $\begin{array}{c}-0.001^{*} \\
(0.001)\end{array}$ & $\begin{array}{c}-0.000^{* *} \\
(0.000)\end{array}$ & $\begin{array}{c}-0.001^{* *} \\
(0.001)\end{array}$ \\
\hline Trigger Level & $\begin{array}{c}0.001 \\
(0.001)\end{array}$ & $\begin{array}{l}0.000^{* *} \\
(0.000)\end{array}$ & $\begin{array}{l}-0.001 \\
(0.001)\end{array}$ \\
\hline Size & $\begin{array}{c}0.000 \\
(0.001)\end{array}$ & $\begin{array}{l}-0.000 \\
(0.000)\end{array}$ & $\begin{array}{c}0.001 \\
(0.001)\end{array}$ \\
\hline Constant & $\begin{array}{c}-0.020^{* * *} \\
(0.005)\end{array}$ & $\begin{array}{c}-0.010^{* * *} \\
(0.001)\end{array}$ & $\begin{array}{c}0.002 \\
(0.017)\end{array}$ \\
\hline
\end{tabular}




\section{Table 6. (Continued)}

\begin{tabular}{|c|c|c|c|}
\hline Variables & $\begin{array}{c}\text { GLS RE } \\
\text { (1) }\end{array}$ & $\begin{array}{c}\text { FGLS } \\
(2)\end{array}$ & $\begin{array}{c}\text { System } \\
\text { GMM } \\
(3)\end{array}$ \\
\hline $\begin{array}{l}\text { Observations } \\
\text { Number of ISIN } \\
\text { Hansen Test } \\
\text { p-value } \\
\text { Arellano-Bond Test for } \operatorname{AR}(1) \\
\text { p-value } \\
\text { Arellano-Bond Test for AR }(2) \\
\text { p-value } \\
\text { Number of Instruments }\end{array}$ & $\begin{array}{c}37,987 \\
82\end{array}$ & $\begin{array}{c}37,987 \\
82\end{array}$ & $\begin{array}{c}37,987 \\
82 \\
80.07 \\
0.114 \\
-1.838 \\
0.066 \\
0.611 \\
0.541 \\
83\end{array}$ \\
\hline \multicolumn{4}{|c|}{$\begin{array}{l}\text { Notes: Estimates of the yield to maturity of the CoCos issued by European banks, } \\
\text { excluding DB. Random-effect GLS estimation with clustered standard errors by } \\
\text { "bank*time" and intragroup correlation is shown in column } 1 \text {; feasible GLS esti- } \\
\text { mation with heteroskedastic error structure across panels and panel-specific AR(1) } \\
\text { process within panels is reported in column } 2 \text {; Blundell-Bond system GMM estimate } \\
\text { is shown in column } 3 \text {. For the GMM, Hansen, AR(1), and AR }(2) \text { tests are provided. } \\
\text { Robust standard errors are in parentheses. }{ }^{* * *} p<0.01,{ }^{* *} p<0.05,{ }^{*} p<0.1 \text {. }\end{array}$} \\
\hline
\end{tabular}

Table 6 shows also that there is limited evidence of co-movement between the CoCos of DB and those of the other banks over the entire time span considered, as the DB's CoCos variable is significant only under the FGLS estimation (column 2). Such significance could be due to unobservable variables that affect all CoCos and that might bias the estimates. In section 8.2 we therefore analyze the robustness of the FGLS results with respect to the possibility of omitted variables.

As for the variables of direct interest to test the CoCo-specific contagion hypothesis described in the previous paragraph, we find that the interaction $Y_{D B, t}$ Dummys,t is positive and very significant across all three alternative estimations during the first stress period (i.e., $s=1$ ); the coefficient of the interacted variable is not different from zero in the second episode (i.e., $s=2$ ), which suggests that no CoCo-specific contagion took place in the second event. This confirms the hypothesis about the existence of CoCo-specific contagion during the first stress episode only. 
The results for the CoCo-specific contagion during the first distress event are also economically significant, albeit to a different extent in the three estimates. The coefficients of the interaction term imply that a 100 basis points higher YTM of the CoCos of DB during the first distress event translates into an average increase of the YTM of the CoCos issued by the other European banks between 1.23 percent (according to the GLS estimate) and 4.09 percent (according to the GMM estimate). With simple algebra it can be shown that the CoCo-specific contagion from DB to the other banks has explained between 18 and 61 percent of the observed increase in the average CoCo YTM of the other banks in the first stress event (i.e., between January 28, 2016 and the peak of the event on February 11, 2016).

The estimated CoCo-specific contagion is not only significant but could be also a lower bound. It is in fact identified as the increase of CoCo yields observed when DB was under distress, additional to what is explained by the fundamental contagion. The assumption does not however consider any negative impact that CoCos yields may have on bank equity prices, one of the variables used to proxy fundamental contagion. This feedback is, however, at least theoretically possible according to Brigo, Garcia, and Pede (2015).

As for the CoCo-specific characteristics, there is evidence of their role in explaining the YTM of CoCos, with four out of five variables being significant under at least one of the estimations. The issuespecific subordination (AT1 versus tier 2) is the more relevant CoCospecific variable, as it is significant across all three estimates, with the negative sign of the coefficient indicating that the more senior the CoCos, the lower their YTM (the higher its price). In terms of loss-absorption mechanism, the variable capturing the alternatives of equity conversion versus principal write-down is not significant, while the variable controlling for the type of principal write-down (i.e., permanent versus temporary) is significant (columns 1 and 2), with the expected positive sign indicating that the CoCos facing the possibility of a permanent writing down have on average a higher YTM. The possibility for the regulator to cancel the interest payments also matters, as the corresponding variable is significant across all the estimations. The negative sign of the coefficient indicates that the CoCos that allow for supervisory judgment in deciding about the suspension of interest payments have a lower YTM (higher price). 
This suggests that a certain degree of flexibility in the decision to impose losses on bondholders is considered to be a risk-reduction factor by investors. Supervisors might have in fact some tolerance in deciding to impose losses if, for instance, the bank has a credible plan to strengthen its solvency. The trigger level is also significant, but only column 2 and its positive coefficient confirm the intuition that the CoCos with a higher trigger have a higher YTM than the CoCos with a lower trigger. The size of the issuance has instead no role in explaining the YTM (and the price) of the CoCos.

Finally, the value of the coefficient of the lag of the CoCo YTMapproximately one - raises some concerns about the presence of a unit root in the CoCos YTM process that could bias our results. We test for this possibility with the Fisher-type test, in essence a Phillips-Perron test robust to general forms of heteroskedasticity (Maddala and $\mathrm{Wu} 1999) 20$ The test rejects the null hypothesis of all panels having a unit root at 1 percent 21 This notwithstanding, to get reassurance about the robustness of the results in table 6 to the presence of a unit root for some CoCos, we reestimate equation (1) on the subsample of CoCos for which the test excludes the possibility of unit root (by doing so we include CoCos from 11 out of 20 banks). The results are broadly unchanged 22

\section{Further Analysis of CoCo-Specific Contagion}

In the previous section we have found evidence on the existence of CoCo-specific contagion during the first DB distress episode that

\footnotetext{
${ }^{20}$ The characteristics of our data make testing for nonstationarity nontrivial: (i) heteroskedasticity poses important limitations to the reliability of test statistics for several tests; (ii) the time horizon considered is somewhat shorter than what is typically required for unit-root testing; (iii) the unbalanced structure with gaps of our panel limits the available tests.

${ }^{21}$ In performing the test we face the usual tradeoff related to the number of lags to be used, between bias (with low number of lags) and variance/errors (with increasing number of lags). In our case the choice should go to zero or a low number of lags, as in financial markets, under the efficient market hypothesis, it should not be possible to use past information to forecast future yields. In any case, this tradeoff does not seem to play an important role for our data, as with lags from 0 to 10 the test always rejects the null hypothesis of all panels having a unit root against the alternative of at least one panel being stationary.

${ }^{22}$ The results of the Fisher-type test and for this robustness test are not shown for brevity but are available on request.
} 
is not explained by the dynamics of banks' fundamental risk. In this section, we further analyze the determinants and implications of contagion.

\subsection{Bank Riskiness and CoCos Dynamics}

To further explore the interaction between fundamental and CoCospecific contagion, we augment the baseline model in equation (1) by the following three triple interactions: (i) $Y_{D B, t}$ Senior $_{j, t}$ Dummy $_{s, t}$, (ii) $Y_{D B, t} E D F_{j, t}$ Dummys,t, and (iii) $Y_{D B, t} C_{i, j, t}$ Dummys,t.

A positive coefficient in the first two interactions and/or a negative coefficient for the third interaction would imply a higher sensitivity of the price of the CoCos issued by the riskier banks to the developments of DB. Such type of behavior would be the one to expect if the dynamics of CoCos were driven by fundamentals, as the CoCos issued by riskier banks are more likely to suffer restrictions on coupon payments or a conversion. In contrast, nonsignificant coefficients would indicate that the interdependence between European banks' CoCos and those issued by DB does not depend on the riskiness of the issuer and would reinforce the evidence of CoCo-specific contagion. The results of the analysis are presented in table 7 . The significance of the interactions of the EDF (columns 1 and 2) and of the distance to trigger (column 2) provides suggestive evidence about a connection between the CoCos market dynamics and the risk of the issuing banks, and points toward the possible existence of a fundamental contagion in the CoCos dynamics in addition to the CoCo-specific contagion during the first DB stress period, which is confirmed by the interaction $Y_{D B, t}$ Dummy $y_{s, t}$. In addition, during the second DB stress event, when the Coco-specific contagion seems to be dispelled - as already shown in table 6 - there is still a fundamental contagion at work in the CoCos dynamics, as confirmed by the significance of the interaction of the EDF across all estimations.

\subsection{Banks'Location, Business Model, and CoCo-Specific Contagion}

To further shed light on the sources of CoCo-specific contagion in the first event, we consider the role played by banks' business model and banks' location. In particular, we investigate whether (i) banks 
Table 7. Fundamental and CoCo-Specific Dependence of CoCos YTM during DB Events: Bank Risk and CoCos YTM Robustness

\begin{tabular}{|c|c|c|c|}
\hline Variables & $\begin{array}{c}\text { GLS RE } \\
(1)\end{array}$ & $\begin{array}{l}\text { FGLS } \\
\quad(2)\end{array}$ & $\begin{array}{l}\text { System } \\
\text { GMM } \\
(3)\end{array}$ \\
\hline Lag CoCo YTM & $\begin{array}{c}0.994^{* * *} \\
(0.002)\end{array}$ & $\begin{array}{c}0.998^{* * *} \\
(0.000)\end{array}$ & $\begin{array}{c}0.993^{* * *} \\
(0.002)\end{array}$ \\
\hline Senior Bond YTM & $\begin{array}{l}0.166^{* *} \\
(0.076)\end{array}$ & $\begin{array}{c}0.039^{* * *} \\
(0.012)\end{array}$ & $\begin{array}{c}0.024 \\
(0.189)\end{array}$ \\
\hline Stock Return & $\begin{array}{c}-0.086^{* * *} \\
(0.012)\end{array}$ & $\begin{array}{c}-0.089^{* * *} \\
(0.002)\end{array}$ & $\begin{array}{l}-0.116 \\
(0.107)\end{array}$ \\
\hline EDF Change & $\begin{array}{l}0.600^{*} \\
(0.348)\end{array}$ & $\begin{array}{l}0.115 \\
(0.121)\end{array}$ & $\begin{array}{c}0.910 \\
(6.224)\end{array}$ \\
\hline Distance to Trigger & $\begin{array}{l}-0.018 \\
(0.012)\end{array}$ & $\begin{array}{c}-0.007^{* * *} \\
(0.003)\end{array}$ & $\begin{array}{l}-0.018 \\
(0.013)\end{array}$ \\
\hline CoCo DB & $\begin{array}{c}0.036 \\
(0.029)\end{array}$ & $\begin{array}{c}0.050^{* * *} \\
(0.008)\end{array}$ & $\begin{array}{l}-0.348 \\
(0.264)\end{array}$ \\
\hline CoCo DB $\times$ Event1 & $\begin{array}{c}1.280^{* * *} \\
(0.171)\end{array}$ & $\begin{array}{c}1.389^{* * *} \\
(0.050)\end{array}$ & $\begin{array}{c}3.836^{* * *} \\
(1.213)\end{array}$ \\
\hline CoCo DB $\times$ Event 2 & $\begin{array}{l}-0.056 \\
(0.128)\end{array}$ & $\begin{array}{l}-0.111 \\
(0.083)\end{array}$ & $\begin{array}{c}0.032 \\
(0.281)\end{array}$ \\
\hline Event1 & $\begin{array}{c}-0.090^{* * *} \\
(0.015)\end{array}$ & $\begin{array}{l}-0.104^{* * *} \\
(0.004)\end{array}$ & $\begin{array}{c}-0.311^{* * *} \\
(0.105)\end{array}$ \\
\hline Event2 & $\begin{array}{l}0.006 \\
(0.009)\end{array}$ & $\begin{array}{c}0.008 \\
(0.006)\end{array}$ & $\begin{array}{l}-0.002 \\
(0.019)\end{array}$ \\
\hline $\begin{array}{l}\text { Senior Bond } \times \text { Event } 1 \\
\times \text { CoCo DB }\end{array}$ & $\begin{array}{l}-1.592 \\
(2.166)\end{array}$ & $\begin{array}{l}-0.129 \\
(0.513)\end{array}$ & $\begin{array}{c}2.710 \\
(4.445)\end{array}$ \\
\hline $\begin{array}{l}\text { Senior Bond } \times \text { Event } 2 \\
\times \text { CoCo DB }\end{array}$ & $\begin{array}{l}1.445 \\
(1.767)\end{array}$ & $\begin{array}{l}1.395 \\
(1.300)\end{array}$ & $\begin{array}{c}2.521 \\
(4.406)\end{array}$ \\
\hline $\begin{array}{l}\text { EDF Change } \times \text { Event } 1 \\
\times \text { CoCo DB }\end{array}$ & $\begin{array}{c}114.151^{* * *} \\
(21.025)\end{array}$ & $\begin{array}{c}64.578^{* * *} \\
(4.581)\end{array}$ & $\begin{array}{l}-51.154 \\
(46.834)\end{array}$ \\
\hline $\begin{array}{l}\text { EDF Change } \times \text { Event } 2 \\
\times \text { CoCo DB }\end{array}$ & $\begin{array}{c}78.747^{* * *} \\
(29.293)\end{array}$ & $\begin{array}{l}35.436^{* *} \\
(15.705)\end{array}$ & $\begin{array}{r}685.167^{* * *} \\
(231.847)\end{array}$ \\
\hline $\begin{array}{l}\text { Distance to Trigger } \times \text { Event } 1 \\
\quad \times \text { CoCo DB }\end{array}$ & $\begin{array}{l}-1.298 \\
(1.167)\end{array}$ & $\begin{array}{l}-0.370^{* * *} \\
(0.113)\end{array}$ & $\begin{array}{c}2.204 \\
(1.977)\end{array}$ \\
\hline $\begin{array}{l}\text { Distance to Trigger } \times \text { Event } 2 \\
\quad \times \text { CoCo DB } \\
\text { CoCos Characteristics: }\end{array}$ & $\begin{array}{l}-0.303 \\
(0.310)\end{array}$ & $\begin{array}{l}-0.069 \\
(0.180)\end{array}$ & $\begin{array}{l}-0.667 \\
(0.509)\end{array}$ \\
\hline Subordination Type & $\begin{array}{c}-0.004^{*} \\
(0.002)\end{array}$ & $\begin{array}{c}-0.001^{* * *} \\
(0.000)\end{array}$ & $\begin{array}{l}-0.005^{* * *} \\
(0.002)\end{array}$ \\
\hline Equity Conversion & $\begin{array}{l}-0.000 \\
(0.001)\end{array}$ & $\begin{array}{c}0.000 \\
(0.000)\end{array}$ & $\begin{array}{l}-0.001 \\
(0.001)\end{array}$ \\
\hline Permanent Write-Down & $\begin{array}{l}0.002^{*} \\
(0.001)\end{array}$ & $\begin{array}{l}0.000^{* *} \\
(0.000)\end{array}$ & $\begin{array}{c}0.001 \\
(0.001)\end{array}$ \\
\hline
\end{tabular}




\section{Table 7. (Continued)}

\begin{tabular}{|c|c|c|c|}
\hline Variables & $\begin{array}{c}\text { GLS RE } \\
(1)\end{array}$ & $\begin{array}{c}\text { FGLS } \\
(2)\end{array}$ & $\begin{array}{c}\text { System } \\
\text { GMM } \\
(3)\end{array}$ \\
\hline Cancellation by Regulators & $\begin{array}{c}-0.001^{*} \\
(0.001)\end{array}$ & $\begin{array}{c}-0.000^{* *} \\
(0.000)\end{array}$ & $\begin{array}{c}-0.002^{* *} \\
(0.001)\end{array}$ \\
\hline Trigger Level & $\begin{array}{c}0.001 \\
(0.001)\end{array}$ & $\begin{array}{c}0.000^{* *} \\
(0.000)\end{array}$ & $\begin{array}{l}-0.001 \\
(0.001)\end{array}$ \\
\hline Size & $\begin{array}{c}0.000 \\
(0.000)\end{array}$ & $\begin{array}{l}-0.000 \\
(0.000)\end{array}$ & $\begin{array}{c}0.001 \\
(0.001)\end{array}$ \\
\hline Constant & $\begin{array}{c}-0.020^{* * *} \\
(0.005)\end{array}$ & $\begin{array}{c}-0.010^{* * *} \\
(0.001)\end{array}$ & $\begin{array}{c}0.007 \\
(0.020)\end{array}$ \\
\hline Observations & 37,987 & 37,987 & 37,987 \\
\hline Number of ISIN & 82 & 82 & 82 \\
\hline Hansen Test & & & 77.49 \\
\hline p-value & & & 0.308 \\
\hline Arellano-Bond Test for AR(1) & & & -1.823 \\
\hline p-value & & & 0.068 \\
\hline Arellano-Bond Test for $\mathrm{AR}(2)$ & & & 0.358 \\
\hline p-value & & & 0.720 \\
\hline Number of Instruments & & & 95 \\
\hline \multicolumn{4}{|c|}{$\begin{array}{l}\text { Notes: Estimates of the yield to maturity of the CoCos issued by European banks, } \\
\text { excluding DB. Random-effect GLS estimation with clustered standard errors by } \\
\text { "bank*time" and intragroup correlation is shown in column 1; feasible GLS esti- } \\
\text { mation with heteroskedastic error structure across panels and panel-specific AR(1) } \\
\text { process within panels is reported in column } 2 \text {; Blundell-Bond system GMM estimate } \\
\text { is shown in column } 3 \text {. For the GMM, Hansen, AR(1), and AR(2) tests are provided. } \\
\text { Robust standard errors are in parentheses. }{ }^{* *} p<0.01,{ }^{* *} p<0.05,{ }^{*} p<0.1 \text {. }\end{array}$} \\
\hline
\end{tabular}

located in the same region as DB, i.e., within the euro area, or (ii) banks with a business model closer to that of DB, i.e. investment banking, might have experienced higher contagion. As for the first test, we define a "euro-area" (EA) dummy, which is equal to 1 if a CoCo has been issued by a bank located in the euro area, and zero otherwise. We then augment equation (1) with $E A_{j}$ and with its interaction with $Y_{D B, t}$ Dummy $y_{s, t}$. The results in table 8 indicate that the YTM of the CoCos issued by euro-area banks are on average higher than those issued by non-euro-area banks, as shown by the positive and significant coefficient of the $E A_{j}$ dummy in the three estimates (columns 1-3). However, the CoCos issued by the euro-area banks do not behave differently vis-à-vis those 
Table 8. Fundamental and CoCo-Specific Dependence of CoCos YTM during DB Events: The Role of Bank Location

\begin{tabular}{|c|c|c|c|}
\hline Variables & $\begin{array}{c}\text { GLS RE } \\
\text { (1) }\end{array}$ & $\begin{array}{l}\text { FGLS } \\
\quad(2)\end{array}$ & $\begin{array}{c}\text { System } \\
\text { GMM } \\
(3)\end{array}$ \\
\hline Lag CoCo YTM & $\begin{array}{c}0.993^{* * *} \\
(0.003)\end{array}$ & $\begin{array}{c}0.997^{* * *} \\
(0.000)\end{array}$ & $\begin{array}{c}0.992^{* * *} \\
(0.002)\end{array}$ \\
\hline Senior Bond YTM & $\begin{array}{l}0.177^{* *} \\
(0.078)\end{array}$ & $\begin{array}{c}0.047^{* * *} \\
(0.012)\end{array}$ & $\begin{array}{l}-0.016 \\
(0.182)\end{array}$ \\
\hline Stock Return & $\begin{array}{c}-0.094^{* * *} \\
(0.012)\end{array}$ & $\begin{array}{c}-0.090^{* * *} \\
(0.002)\end{array}$ & $\begin{array}{l}-0.121 \\
(0.094)\end{array}$ \\
\hline EDF Change & $\begin{array}{c}1.208^{* * *} \\
(0.324)\end{array}$ & $\begin{array}{c}0.449^{* * *} \\
(0.117)\end{array}$ & $\begin{array}{c}5.048 \\
(4.011)\end{array}$ \\
\hline Distance to Trigger & $\begin{array}{c}-0.016^{*} \\
(0.009)\end{array}$ & $\begin{array}{c}-0.009^{* * *} \\
(0.003)\end{array}$ & $\begin{array}{l}-0.001 \\
(0.015)\end{array}$ \\
\hline CoCo DB & $\begin{array}{c}0.037 \\
(0.030)\end{array}$ & $\begin{array}{c}0.058^{* * *} \\
(0.009)\end{array}$ & $\begin{array}{l}-0.345 \\
(0.251)\end{array}$ \\
\hline CoCo DB $\times$ Event1 & $\begin{array}{c}1.213^{* * *} \\
(0.222)\end{array}$ & $\begin{array}{c}1.457^{* * *} \\
(0.049)\end{array}$ & $\begin{array}{l}4.822^{* *} \\
(2.000)\end{array}$ \\
\hline CoCo DB × Event2 & $\begin{array}{l}-0.052 \\
(0.124)\end{array}$ & $\begin{array}{l}-0.070 \\
(0.083)\end{array}$ & $\begin{array}{c}0.173 \\
(0.197)\end{array}$ \\
\hline Event1 & $\begin{array}{l}-0.095^{* * *} \\
(0.015)\end{array}$ & $\begin{array}{c}-0.111^{* * *} \\
(0.004)\end{array}$ & $\begin{array}{c}-0.369^{* *} \\
(0.152)\end{array}$ \\
\hline Event2 & $\begin{array}{c}0.005 \\
(0.009)\end{array}$ & $\begin{array}{c}0.006 \\
(0.006)\end{array}$ & $\begin{array}{l}-0.011 \\
(0.014)\end{array}$ \\
\hline Euro-Area Bank & $\begin{array}{l}0.001^{*} \\
(0.001)\end{array}$ & $\begin{array}{c}0.001^{* * *} \\
(0.000)\end{array}$ & $\begin{array}{l}0.002^{* *} \\
(0.001)\end{array}$ \\
\hline $\begin{array}{l}\text { Euro-Area Bank } \times \\
\text { Event } 1 \times \text { CoCo DB }\end{array}$ & $\begin{array}{c}0.031 \\
(0.046)\end{array}$ & $\begin{array}{l}-0.008 \\
(0.006)\end{array}$ & $\begin{array}{l}-0.105 \\
(0.073)\end{array}$ \\
\hline $\begin{array}{l}\text { Euro-Area Bank } \times \\
\text { Event } 2 \times \text { CoCo DB } \\
\text { CoCos Characteristics: }\end{array}$ & $\begin{array}{c}0.009 \\
(0.011)\end{array}$ & $\begin{array}{c}0.001 \\
(0.008)\end{array}$ & $\begin{array}{c}0.018 \\
(0.021)\end{array}$ \\
\hline Subordination Type & $\begin{array}{c}-0.003^{*} \\
(0.002)\end{array}$ & $\begin{array}{l}-0.001^{* * *} \\
(0.000)\end{array}$ & $\begin{array}{l}-0.005^{* * *} \\
(0.001)\end{array}$ \\
\hline Equity Conversion & $\begin{array}{c}0.000 \\
(0.000)\end{array}$ & $\begin{array}{l}0.000^{*} \\
(0.000)\end{array}$ & $\begin{array}{l}-0.000 \\
(0.001)\end{array}$ \\
\hline Permanent Write-Down & $\begin{array}{l}0.003^{*} \\
(0.001)\end{array}$ & $\begin{array}{c}0.001^{* * *} \\
(0.000)\end{array}$ & $\begin{array}{c}0.002 \\
(0.001)\end{array}$ \\
\hline Cancellation by Regulators & $\begin{array}{l}-0.001 \\
(0.000)\end{array}$ & $\begin{array}{l}-0.000^{* *} \\
(0.000)\end{array}$ & $\begin{array}{c}-0.001^{* *} \\
(0.001)\end{array}$ \\
\hline Trigger Level & $\begin{array}{c}0.000 \\
(0.001)\end{array}$ & $\begin{array}{c}0.000 \\
(0.000)\end{array}$ & $\begin{array}{l}-0.002 \\
(0.001)\end{array}$ \\
\hline Size & $\begin{array}{c}0.001 \\
(0.001)\end{array}$ & $\begin{array}{l}-0.000 \\
(0.000)\end{array}$ & $\begin{array}{c}0.001 \\
(0.001)\end{array}$ \\
\hline Constant & $\begin{array}{c}-0.023^{* * *} \\
(0.007)\end{array}$ & $\begin{array}{c}-0.013^{* * *} \\
(0.001)\end{array}$ & $\begin{array}{c}0.003 \\
(0.018)\end{array}$ \\
\hline
\end{tabular}


Table 8. (Continued)

\begin{tabular}{|c|c|c|c|}
\hline Variables & $\begin{array}{l}\text { GLS RE } \\
(1)\end{array}$ & $\begin{array}{c}\text { FGLS } \\
\quad(2)\end{array}$ & $\begin{array}{c}\text { System } \\
\text { GMM } \\
(3)\end{array}$ \\
\hline $\begin{array}{l}\text { Observations } \\
\text { Number of ISIN } \\
\text { Hansen Test } \\
\text { p-value } \\
\text { Arellano-Bond Test for AR }(1) \\
\text { p-value } \\
\text { Arellano-Bond Test for AR }(2) \\
\text { p-value } \\
\text { Number of Instruments }\end{array}$ & $\begin{array}{c}37,987 \\
82\end{array}$ & $\begin{array}{c}37,987 \\
82\end{array}$ & $\begin{array}{c}37,987 \\
82 \\
78.95 \\
0.099 \\
-1.834 \\
0.0666 \\
0.796 \\
0.426 \\
84\end{array}$ \\
\hline \multicolumn{4}{|c|}{$\begin{array}{l}\text { Notes: Estimates of the yield to maturity of the CoCos issued by European banks, } \\
\text { excluding DB. Random-effect GLS estimation with clustered standard errors by } \\
\text { "bank*time" and intragroup correlation is shown in column 1; feasible GLS esti- } \\
\text { mation with heteroskedastic error structure across panels and panel-specific AR(1) } \\
\text { process within panels is reported in column } 2 \text {; Blundell-Bond system GMM estimate } \\
\text { is shown in column } 3 \text {. For the GMM, Hansen, AR(1), and AR(2) tests are provided. } \\
\text { Robust standard errors are in parentheses. }{ }^{* * *} p<0.01,{ }^{* *} p<0.05,{ }^{*} p<0.1 \text {. }\end{array}$} \\
\hline
\end{tabular}

issued by the non-euro-area banks during the DB stress periods, as shown by the nonsignificance of the triple interaction. Hence the bank's location has no role in the transmission of the CoCo-specific contagion.

As for the second test, using information from banks' balance sheet at the end of 2016, we consider a bank to be an "investment bank" (IB) if its trading assets account for more than 30 percent of its total assets. We then define a dummy variable $I B_{j}$ which captures whether a bank $j$ 's business model is IB or not, and estimate again equation (1) augmented by $I B_{j}$ and its interaction with $Y_{D B, t}$ Dummys,t. The results in table 9 show that investment banks might face on average a higher CoCo YTM, as indicated by the positive coefficient of the $I B_{j}$ dummy in column 3 . More importantly in the context of the analysis, they also indicate that investment banks experience more severe CoCo-specific contagion during the first DB distress event, as shown by the significance of the coefficient of the triple interaction $I B_{j} Y_{D B, t}$ Dummy $y_{s, t}$ (column 2). 
Table 9. Fundamental and CoCo-Specific Dependence of CoCos YTM during DB Events: The Role of Bank Business Model

\begin{tabular}{|c|c|c|c|}
\hline Variables & $\begin{array}{c}\text { GLS RE } \\
\text { (1) }\end{array}$ & $\begin{array}{l}\text { FGLS } \\
\quad(2)\end{array}$ & $\begin{array}{c}\text { System } \\
\text { GMM } \\
(3)\end{array}$ \\
\hline Lag CoCo YTM & $\begin{array}{c}0.994^{* * *} \\
(0.002)\end{array}$ & $\begin{array}{c}0.997^{* * *} \\
(0.000)\end{array}$ & $\begin{array}{c}0.987^{* * *} \\
(0.005)\end{array}$ \\
\hline Senior Bond YTM & $\begin{array}{l}0.162^{* *} \\
(0.076)\end{array}$ & $\begin{array}{c}0.042^{* * *} \\
(0.012)\end{array}$ & $\begin{array}{c}0.224 \\
(0.203)\end{array}$ \\
\hline Stock Return & $\begin{array}{c}-0.094^{* * *} \\
(0.012)\end{array}$ & $\begin{array}{l}-0.092^{* * *} \\
(0.002)\end{array}$ & $\begin{array}{c}-0.104^{*} \\
(0.062)\end{array}$ \\
\hline EDF Change & $\begin{array}{c}1.192^{* * *} \\
(0.329)\end{array}$ & $\begin{array}{c}0.395^{* * *} \\
(0.118)\end{array}$ & $\begin{array}{c}4.370 \\
(3.076)\end{array}$ \\
\hline Distance to Trigger & $\begin{array}{c}-0.020^{*} \\
(0.011)\end{array}$ & $\begin{array}{c}-0.008^{* * *} \\
(0.003)\end{array}$ & $\begin{array}{c}0.103 \\
(0.064)\end{array}$ \\
\hline CoCo DB & $\begin{array}{c}0.036 \\
(0.029)\end{array}$ & $\begin{array}{c}0.053^{* * *} \\
(0.008)\end{array}$ & $\begin{array}{l}-0.318 \\
(0.238)\end{array}$ \\
\hline CoCo DB $\times$ Event1 & $\begin{array}{c}1.221^{* * *} \\
(0.209)\end{array}$ & $\begin{array}{c}1.411^{* * *} \\
(0.048)\end{array}$ & $\begin{array}{l}4.454^{* *} \\
(1.854)\end{array}$ \\
\hline CoCo DB $\times$ Event 2 & $\begin{array}{l}-0.047 \\
(0.123)\end{array}$ & $\begin{array}{l}-0.094 \\
(0.082)\end{array}$ & $\begin{array}{c}0.254 \\
(0.227)\end{array}$ \\
\hline Event1 & $\begin{array}{l}-0.095^{* * *} \\
(0.015)\end{array}$ & $\begin{array}{c}-0.108^{* * *} \\
(0.004)\end{array}$ & $\begin{array}{c}-0.343^{* *} \\
(0.142)\end{array}$ \\
\hline Event2 & $\begin{array}{c}0.004 \\
(0.009)\end{array}$ & $\begin{array}{c}0.007 \\
(0.006)\end{array}$ & $\begin{array}{l}-0.017 \\
(0.016)\end{array}$ \\
\hline Investment Bank & $\begin{array}{c}0.001 \\
(0.000)\end{array}$ & $\begin{array}{c}0.000 \\
(0.000)\end{array}$ & $\begin{array}{l}0.024^{* *} \\
(0.009)\end{array}$ \\
\hline $\begin{array}{l}\text { Investment Bank } \times \text { Event } 1 \\
\quad \times \text { CoCo DB }\end{array}$ & $\begin{array}{c}0.047 \\
(0.037)\end{array}$ & $\begin{array}{c}0.018^{* * *} \\
(0.007)\end{array}$ & $\begin{array}{l}-0.047 \\
(0.047)\end{array}$ \\
\hline $\begin{array}{l}\text { Investment Bank } \times \text { Event } 2 \\
\quad \times \text { CoCo DB } \\
\text { CoCos Characteristics }:\end{array}$ & $\begin{array}{c}0.003 \\
(0.012)\end{array}$ & $\begin{array}{c}0.001 \\
(0.009)\end{array}$ & $\begin{array}{c}0.039 \\
(0.030)\end{array}$ \\
\hline Subordination Type & $\begin{array}{c}-0.004^{*} \\
(0.002)\end{array}$ & $\begin{array}{c}-0.001^{* * *} \\
(0.000)\end{array}$ & $\begin{array}{c}-0.012^{* *} \\
(0.006)\end{array}$ \\
\hline Equity Conversion & $\begin{array}{l}-0.000 \\
(0.001)\end{array}$ & $\begin{array}{c}0.000 \\
(0.000)\end{array}$ & $\begin{array}{c}0.004 \\
(0.004)\end{array}$ \\
\hline Permanent Write-Down & $\begin{array}{l}0.002^{*} \\
(0.001)\end{array}$ & $0.001^{* *}$ & $\begin{array}{c}0.008 \\
(0.005)\end{array}$ \\
\hline Cancellation by Regulators & $\begin{array}{c}-0.001^{*} \\
(0.001)\end{array}$ & $\begin{array}{c}-0.000^{* *} \\
(0.000)\end{array}$ & $\begin{array}{c}-0.007^{*} \\
(0.004)\end{array}$ \\
\hline Trigger Level & $\begin{array}{c}0.001 \\
(0.001)\end{array}$ & $\begin{array}{l}0.000^{* *} \\
(0.000)\end{array}$ & $\begin{array}{c}0.002 \\
(0.003)\end{array}$ \\
\hline Size & $\begin{array}{c}0.000 \\
(0.001)\end{array}$ & $\begin{array}{l}-0.000 \\
(0.000)\end{array}$ & $\begin{array}{l}-0.000 \\
(0.003)\end{array}$ \\
\hline Constant & $\begin{array}{c}-0.020^{* * *} \\
(0.006)\end{array}$ & $-0.011^{* * *}$ & $\begin{array}{l}-0.028 \\
(0.020)\end{array}$ \\
\hline
\end{tabular}




\section{Table 9. (Continued)}

\begin{tabular}{|c|c|c|c|}
\hline Variables & $\begin{array}{c}\text { GLS RE } \\
(1)\end{array}$ & $\begin{array}{c}\text { FGLS } \\
(2)\end{array}$ & $\begin{array}{c}\text { System } \\
\text { GMM } \\
(3)\end{array}$ \\
\hline $\begin{array}{l}\text { Observations } \\
\text { Number of ISIN } \\
\text { Hansen Test } \\
\text { p-value } \\
\text { Arellano-Bond Test for AR(1) } \\
\text { p-value } \\
\text { Arellano-Bond Test for AR(2) } \\
\text { p-value } \\
\text { Number of Instruments }\end{array}$ & $\begin{array}{c}37,987 \\
82\end{array}$ & $\begin{array}{c}37,987 \\
82\end{array}$ & $\begin{array}{c}37,987 \\
82 \\
78.67 \\
0.249 \\
-1.826 \\
0.068 \\
0.669 \\
0.504 \\
91\end{array}$ \\
\hline \multicolumn{4}{|c|}{$\begin{array}{l}\text { Notes: Estimates of the yield to maturity of the CoCos issued by European banks, } \\
\text { excluding DB. Random-effect GLS estimation with clustered standard errors by } \\
\text { "bank*time" and intragroup correlation is shown in column } 1 \text {; feasible GLS esti- } \\
\text { mation with heteroskedastic error structure across panels and panel-specific AR(1) } \\
\text { process within panels is reported in column } 2 \text {; Blundell-Bond system GMM estimate } \\
\text { is shown in column 3. For the GMM, Hansen, AR(1), and AR }(2) \text { tests are provided. } \\
\text { Robust standard errors are in parentheses. }{ }^{* * *} p<0.01,{ }^{* *} p<0.05,{ }^{*} p<0.1 \text {. }\end{array}$} \\
\hline
\end{tabular}

\subsection{Heterogeneity in CoCo-Specific Contagion}

The results discussed so far describe the average features of our sample of CoCos issued by European banks. An interesting question is how "representative" these numbers are: does the CoCo-specific contagion during the DB events differ significantly and systematically across CoCo issues? The large-T nature of our panel allows us to answer this question by estimating issue-specific model and scrutinizing the cross-sectional distributions of the coefficients. The results confirm the findings of the panel estimation. Figure 3 shows the distribution of the coefficients of $Y_{D B, t}$ Dummy s,$t_{t}$ obtained from ordinary least squares (OLS) estimates of equation (1) performed ISIN by ISIN. The estimated coefficients appear to be a good summary of the data, as the banks' CoCo YTM are indeed positively correlated with the YTM of the DB CoCos in the first event. Coherently with the panel estimates, the distribution of the estimated coefficients for the first turbulent period has both mean and median at about 1.3, while that for the second period has both a negative mean (at about -0.6 ) and a negative median (at about -0.4 ), with a negative skew. 


\section{Figure 3. Cross-Sectional Distribution of the Estimated CoCo $\times$ DB Interacted Coefficients}
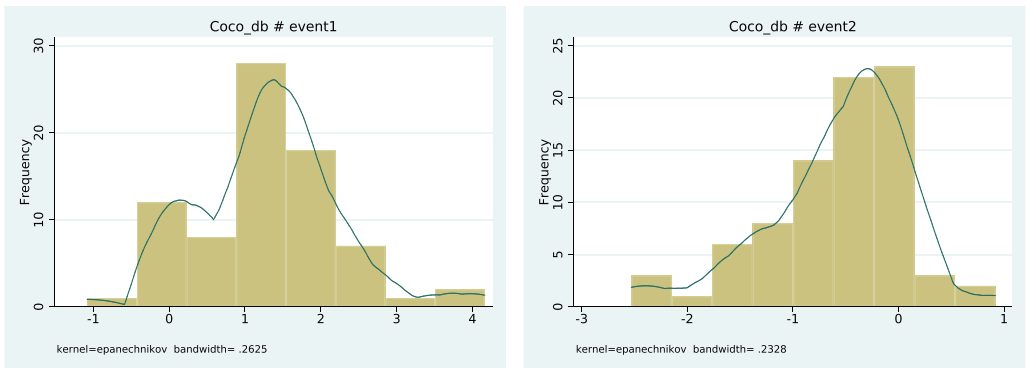

Table 10. Significance of CoCo-Specific Contagion across Issue-Specific OLS Regressions

\begin{tabular}{|l|c|c|}
\hline \multicolumn{2}{|c|}{ Estimated Significant Coefficients (Share of Total Estimates) } \\
\hline Significance Level & CoCo DB $\times$ Event1 & CoCo DB $\times$ Event2 \\
\hline Up to 1 Percent & 0.54 & 0.14 \\
1 to 5 Percent & 0.27 & 0.13 \\
Up to 5 Percent & 0.80 & 0.26 \\
\hline
\end{tabular}

The share of significant coefficients of $Y_{D B, t}$ Dummy $y_{s, t}$ across the OLS estimates of equation (1) performed ISIN by ISIN is shown in table 10. The share of significant coefficients (at either the 1 or 5 percent level) of the ISIN-by-ISIN estimates is much higher in the first stress event, with 80 percent of the estimated coefficient being significant. The statistically significant coefficients involve almost all issuers (84 percent). The estimated coefficients are instead significant, with a much lower frequency in the second stress event (26 percent of the times) and for less than half of the banks in the sample (42 percent). What is also worth noting is that the coefficients relative to the second event, when significant, have always a negative sign, while in the first event all but two of the higher number of estimated coefficients have a positive sign. The key message is therefore that our panel estimations provide a good description for most CoCo issues in the sample. 


\subsection{Financial Stability Implications of CoCo-Specific Contagion}

In this section we study the effects of the distress of DB and of CoCo-specific contagion on the insolvency risk of the banks in the sample. This allows us to assess the financial stability implications of the CoCo-specific contagion. Using the results in section 7.3, we construct a new bank variable, $\operatorname{Exp}_{j}$, which is the average at bank level of the coefficients of $Y_{D B, t}$ Dummy $y_{s, t}$ estimated across all the CoCos $i$ issued by bank $j$. The average is computed under the convention that nonsignificant or negative coefficients are set to zero and the significantly positive coefficients are set at their estimated value. A positive value of $E x p_{j}$ indicates that a bank is exposed to the first DB distress via the CoCo-specific contagion channel, and the higher the value, the higher the exposure. We then estimate the following equation:

$$
\begin{aligned}
Y_{i, j, t}= & \alpha_{i, j}+\beta Y_{i, j, t-1}+\delta \log \left(Y_{D B, t}\right)+\gamma \operatorname{Dumm}_{1, t} \\
& +\eta \log \left(Y_{D B, t} \text { Dummy }_{1, t}\right) \\
& +\varrho \operatorname{Exp}_{j, t}+\varphi \operatorname{Exp}_{j} \text { Dummy }_{1, t} \\
& +\theta \operatorname{Exp}_{j} \log \left(Y_{D B, t} \text { Dummy }_{1, t}\right),
\end{aligned}
$$

where the dependent variable $Y_{i, j, t}$ is the daily YTM of senior bond $i$ issued by bank $j$ at time $t$. This variable proxies the bank's solvency risk as perceived by the market. The regressors are (i) the dependent variable lagged by one period to account for serial correlation, $Y_{i, j, t-1}$; (ii) the daily average YTM of the CoCos issued by DB taken in logarithm to account for possible nonlinearities in the estimated relation, $\log \left(Y_{D B, t}\right)$; (iii) the dummy Dummy $y_{1, t}$ which identifies the first distress event; (iv) the interaction of Dummy $y_{1, t}$ with $\log \left(Y_{D B, t}\right)$; (v) $\operatorname{Exp}_{j}$ to control for banks' exposure to CoCo-specific contagion; (vi) the interaction of the exposure variable $E x p_{j}$ with Dummy $y_{1, t}$; and (vii) the triple interaction between $\operatorname{Exp}_{j}, \log \left(Y_{D B, t}\right)$ and Dummy $y_{1, t}$.

Our focus is on the coefficients of Dummy $y_{1, t}$ and of the three interactions $\log \left(Y_{D B, t} D_{\text {ummy }}\right)$, Dummy $_{1, t} \operatorname{Exp}_{j}$, and $\log \left(Y_{D B, t}\right.$ Dummy $\left._{1, t} \operatorname{Exp}_{j}\right)$ : (i) a positive coefficient of Dummy $y_{1, t}$ would indicate a negative effect of the stress of DB on other banks' solvency; (ii) a positive coefficient of $\log \left(Y_{D B, t}\right.$ Dummy $\left.y_{1, t}\right)$ 
would be evidence of a CoCo-specific contagion on the banks' solvency; (iii) positive coefficients of Dummy ${ }_{1, t} \operatorname{Exp}_{j}$ and $\log \left(Y_{D B, t}\right.$ Dummy $\left._{1, t} \operatorname{Exp}_{j}\right)$ would instead indicate that the negative repercussions would have been more severe for the banks more exposed to DB through the CoCo-specific contagion channel.

The results from the estimation of equation (2) are shown in table 11, with the GLS estimation reported in column 1, the FGLS in column 2, and the system GMM in column 3.

The findings across the three different estimations show that around the first distress event there are negative implications from the stress of $\mathrm{DB}$ on the financial condition of other banks, which go beyond the documented contagion that occurred within the CoCos market. This is indicated by the positive coefficient of Dummy $y_{1, t}$. At the same time, these negative implications have been augmented by the deterioration in the conditions of DB CoCos, thereby indicating that the CoCo-specific contagion has affected not only other banks' CoCos but also banks' senior bonds, as suggested by the positive coefficient of $\log \left(Y_{D B, t}\right.$ Dummy $\left.y_{1, t}\right)$. There has not been however a differential impact of the distress of $\mathrm{DB}$ and of the CoCospecific contagion for those banks with a higher exposure to DB, as shown by the nonsignificant coefficients of Dummy ${ }_{1, t} \operatorname{Exp}_{j}$ and $\log \left(Y_{D B, t}\right.$ Dummy $\left._{1, t} \operatorname{Exp}_{j}\right)$.

\section{Robustness}

In this section we conduct two robustness exercises. First we deepen the analysis about the possible role of nonlinearities, and second we check the validity of our results against the existence of omitted variables.

\subsection{Nonlinearities in CoCo Prices during Stress Events}

As an additional robustness exercise, we test the validity of our results against nonlinearities between bank risk and the price of CoCos during the two DB distress periods, in addition to what is already captured by the log-linear specification used. We do so by estimating equation (1) augmented by the interactions $X_{k, j, t}$ Dummy $_{s, t}$, that is, between the two dummy events and, respectively, the senior bond YTM, the stock return, and the EDF 


\section{Table 11. Implications of CoCo-Specific Contagion for Bank Enterprise Value}

\begin{tabular}{|c|c|c|c|}
\hline Variables & $\underset{(1)}{\text { GLS RE }}$ & $\begin{array}{l}\text { FGLS } \\
\quad(2)\end{array}$ & $\begin{array}{c}\text { System } \\
\text { GMM } \\
(3)\end{array}$ \\
\hline Lag Senior Bond YTM & $\begin{array}{c}0.970^{* * *} \\
(0.007)\end{array}$ & $\begin{array}{c}1.000^{* * *} \\
(0.000)\end{array}$ & $\begin{array}{c}1.006^{* * *} \\
(0.007)\end{array}$ \\
\hline Log CoCo DB YTM & $\begin{array}{c}-8.547^{* * *} \\
(2.332)\end{array}$ & $\begin{array}{c}0.555^{* * *} \\
(0.086)\end{array}$ & $\begin{array}{l}3.364^{*} \\
(2.016)\end{array}$ \\
\hline Event1 & $\begin{array}{c}89.229^{* * *} \\
(28.663)\end{array}$ & $\begin{array}{c}40.824^{* * *} \\
(5.163)\end{array}$ & $\begin{array}{c}23.242 \\
(31.935)\end{array}$ \\
\hline Event1 $\times \log ($ CoCo DB $)$ & $\begin{array}{c}33.971^{* * *} \\
(11.272)\end{array}$ & $\begin{array}{c}15.888^{* * *} \\
(2.022)\end{array}$ & $\begin{array}{c}9.167 \\
(12.484)\end{array}$ \\
\hline Exp. to DB & $\begin{array}{l}-0.770 \\
(0.469)\end{array}$ & $\begin{array}{c}0.064 \\
(0.053)\end{array}$ & $\begin{array}{l}-0.674 \\
(0.484)\end{array}$ \\
\hline Exp. to DB $\times$ Event 1 & $\begin{array}{c}-9.839 \\
(68.222)\end{array}$ & $\begin{array}{l}-19.193 \\
(12.314)\end{array}$ & $\begin{array}{c}54.288 \\
(58.917)\end{array}$ \\
\hline $\begin{array}{l}\text { Exp. to } \mathrm{DB} \times \text { Event } 1 \\
\quad \times \log (\mathrm{CoCo} \mathrm{DB})\end{array}$ & $\begin{array}{l}-2.977 \\
(26.887)\end{array}$ & $\begin{array}{l}-7.318 \\
(4.825)\end{array}$ & $\begin{array}{l}21.410 \\
(23.202)\end{array}$ \\
\hline Constant & $\begin{array}{c}-19.399^{* * *} \\
(5.364)\end{array}$ & $\begin{array}{c}1.318^{* * *} \\
(0.235)\end{array}$ & $\begin{array}{l}8.449^{*} \\
(4.675)\end{array}$ \\
\hline Observations & 124,776 & 124,776 & 124,776 \\
\hline Number of ISIN & 346 & 346 & 346 \\
\hline Hansen Test & & & 266.5 \\
\hline $\begin{array}{l}\text { p-value } \\
\text { Arellano-Bond Test for AR }(1)\end{array}$ & & & $\begin{array}{c}0 \\
-3.393\end{array}$ \\
\hline p-value & & & 0.000690 \\
\hline Arellano-Bond Test for $\mathrm{AR}(2)$ & & & -0.762 \\
\hline p-value & & & 0.446 \\
\hline Number of Instruments & & & 50 \\
\hline \multicolumn{4}{|c|}{$\begin{array}{l}\text { Notes: Estimates of the yield to maturity of the CoCos issued by European banks, } \\
\text { excluding DB. Random-effect GLS estimation with clustered standard errors by } \\
\text { "bank*time" and intragroup correlation is shown in column } 1 \text {; feasible GLS esti- } \\
\text { mation with heteroskedastic error structure across panels and panel-specific AR(1) } \\
\text { process within panels is reported in column } 2 \text {; Blundell-Bond system GMM estimate } \\
\text { is shown in column } 3 \text {. For the GMM, Hansen, AR(1), and AR(2) tests are provided } \\
\text { Robust standard errors are in parentheses. }{ }^{* * *} p<0.01 \text {, }{ }^{* *} p<0.05,{ }^{*} p<0.1 \text {. }\end{array}$} \\
\hline
\end{tabular}

change of bank $j$. The results in table 12 confirm the validity of our findings, as the significance of the coefficients of $Y_{D B, t}$ Dummy $y_{s, t}$ is unchanged relative to table 6 . They also indicate that indeed there are nonlinearities in the relationship between the bank risk and the price of its CoCos during the first DB distress period, as confirmed 
Table 12. Fundamental and CoCo-Specific Dependence of CoCos YTM during DB Events: Nonlinearities in the Price of Bank Risk

\begin{tabular}{|c|c|c|c|}
\hline Variables & $\begin{array}{l}\text { GLS RE } \\
\text { (1) }\end{array}$ & $\begin{array}{l}\text { FGLS } \\
(2)\end{array}$ & $\begin{array}{l}\text { System } \\
\text { GMM } \\
(3)\end{array}$ \\
\hline Lag CoCo YTM & $\begin{array}{c}0.994^{* * *} \\
(0.002)\end{array}$ & $\begin{array}{c}0.997^{* * *} \\
(0.000)\end{array}$ & $\begin{array}{c}0.993^{* * *} \\
(0.001)\end{array}$ \\
\hline Senior Bond YTM & $\begin{array}{l}0.158^{* *} \\
(0.073)\end{array}$ & $\begin{array}{c}0.040^{* * *} \\
(0.012)\end{array}$ & $\begin{array}{l}-0.027 \\
(0.201)\end{array}$ \\
\hline Stock Return & $\begin{array}{c}-0.079^{* * *} \\
(0.011)\end{array}$ & $\begin{array}{c}-0.086^{* * *} \\
(0.002)\end{array}$ & $\begin{array}{c}-0.228^{* * *} \\
(0.051)\end{array}$ \\
\hline EDF Change & $\begin{array}{l}0.800^{* *} \\
(0.315)\end{array}$ & $\begin{array}{c}0.159 \\
(0.121)\end{array}$ & $\begin{array}{l}-2.366 \\
(3.906)\end{array}$ \\
\hline Distance to Trigger & $\begin{array}{c}-0.023^{* *} \\
(0.012)\end{array}$ & $\begin{array}{c}-0.010^{* * *} \\
(0.003)\end{array}$ & $\begin{array}{l}-0.008 \\
(0.012)\end{array}$ \\
\hline CoCo DB & $\begin{array}{c}0.035 \\
(0.029)\end{array}$ & $\begin{array}{c}0.054^{* * *} \\
(0.008)\end{array}$ & $\begin{array}{l}-0.367 \\
(0.280)\end{array}$ \\
\hline CoCo DB × Event1 & $\begin{array}{c}1.165^{* * *} \\
(0.208)\end{array}$ & $\begin{array}{c}1.399^{* * *} \\
(0.048)\end{array}$ & $\begin{array}{c}3.455^{* * *} \\
(0.825)\end{array}$ \\
\hline CoCo DB $\times$ Event 2 & $\begin{array}{l}-0.057 \\
(0.123)\end{array}$ & $\begin{array}{l}-0.078 \\
(0.082)\end{array}$ & $\begin{array}{c}0.010 \\
(0.255)\end{array}$ \\
\hline Event1 & $\begin{array}{c}-0.092^{* * *} \\
(0.014)\end{array}$ & $\begin{array}{c}-0.108^{* * *} \\
(0.004)\end{array}$ & $\begin{array}{c}-0.266^{* * *} \\
(0.063)\end{array}$ \\
\hline Event2 & $\begin{array}{c}0.004 \\
(0.009)\end{array}$ & $\begin{array}{c}0.005 \\
(0.006)\end{array}$ & $\begin{array}{l}-0.002 \\
(0.018)\end{array}$ \\
\hline Senior Bond YTM $\times$ Event1 & $\begin{array}{c}0.160 \\
(0.194)\end{array}$ & $\begin{array}{l}0.054 \\
(0.039)\end{array}$ & $\begin{array}{l}-0.001 \\
(0.132)\end{array}$ \\
\hline Senior Bond YTM $\times$ Event2 & $\begin{array}{c}0.170 \\
(0.128)\end{array}$ & $\begin{array}{c}0.137 \\
(0.103)\end{array}$ & $\begin{array}{c}0.242 \\
(0.301)\end{array}$ \\
\hline Stock Return $\times$ Event 1 & $\begin{array}{l}-0.076 \\
(0.072)\end{array}$ & $\begin{array}{c}-0.014^{*} \\
(0.008)\end{array}$ & $\begin{array}{c}0.358^{* * *} \\
(0.115)\end{array}$ \\
\hline Stock Return $\times$ Event2 & $\begin{array}{l}-0.046 \\
(0.032)\end{array}$ & $\begin{array}{l}-0.024 \\
(0.021)\end{array}$ & $\begin{array}{l}-0.111 \\
(0.078)\end{array}$ \\
\hline EDF Change $\times$ Event 1 & $\begin{array}{l}5.491^{*} \\
(2.924)\end{array}$ & $\begin{array}{c}5.173^{* * *} \\
(0.549)\end{array}$ & $\begin{array}{c}16.751^{* *} \\
(8.035)\end{array}$ \\
\hline $\begin{array}{l}\text { EDF Change } \times \text { Event } 2 \\
\text { CoCos Characteristics: }\end{array}$ & $\begin{array}{c}3.378 \\
(2.531)\end{array}$ & $\begin{array}{c}1.511 \\
(1.649)\end{array}$ & $\begin{array}{l}10.627 \\
(7.096)\end{array}$ \\
\hline Subordination Type & $\begin{array}{c}-0.004^{*} \\
(0.002)\end{array}$ & $\begin{array}{l}-0.001^{* * *} \\
(0.000)\end{array}$ & $\begin{array}{c}-0.005^{* * *} \\
(0.001)\end{array}$ \\
\hline Equity Conversion & $\begin{array}{l}-0.000 \\
(0.001)\end{array}$ & $\begin{array}{c}0.000 \\
(0.000)\end{array}$ & $\begin{array}{l}-0.001 \\
(0.001)\end{array}$ \\
\hline Permanent Write-Down & $\begin{array}{l}0.002^{*} \\
(0.001)\end{array}$ & $\begin{array}{c}0.001^{* *} \\
(0.000)\end{array}$ & $\begin{array}{c}0.001 \\
(0.001)\end{array}$ \\
\hline
\end{tabular}


Table 12. (Continued)

\begin{tabular}{|c|c|c|c|}
\hline Variables & $\begin{array}{c}\text { GLS RE } \\
\text { (1) }\end{array}$ & $\begin{array}{c}\text { FGLS } \\
(2)\end{array}$ & $\begin{array}{c}\text { System } \\
\text { GMM } \\
(3)\end{array}$ \\
\hline Cancellation by Regulators & $\begin{array}{c}-0.001^{*} \\
(0.001)\end{array}$ & $\begin{array}{c}-0.000^{* *} \\
(0.000)\end{array}$ & $\begin{array}{c}-0.001^{* *} \\
(0.001)\end{array}$ \\
\hline Trigger Level & $\begin{array}{c}0.001 \\
(0.001)\end{array}$ & $\begin{array}{c}0.000^{* *} \\
(0.000)\end{array}$ & $\begin{array}{l}-0.001 \\
(0.001)\end{array}$ \\
\hline Size & $\begin{array}{c}0.000 \\
(0.001)\end{array}$ & $\begin{array}{l}-0.000 \\
(0.000)\end{array}$ & $\begin{array}{c}0.000 \\
(0.001)\end{array}$ \\
\hline Constant & $\begin{array}{c}-0.019^{* * *} \\
(0.005)\end{array}$ & $\begin{array}{c}-0.011^{* * *} \\
(0.001)\end{array}$ & $\begin{array}{c}0.009 \\
(0.021)\end{array}$ \\
\hline Observations & 37,987 & 37,987 & 37,987 \\
\hline Number of ISIN & 82 & 82 & 82 \\
\hline Hansen Test & & & 78.90 \\
\hline p-value & & & 0.270 \\
\hline Arellano-Bond Test for AR(1) & & & -1.837 \\
\hline p-value & & & 0.066 \\
\hline Arellano-Bond Test for $\mathrm{AR}(2)$ & & & 0.337 \\
\hline p-value & & & 0.736 \\
\hline Number of Instruments & & & 95 \\
\hline \multicolumn{4}{|c|}{$\begin{array}{l}\text { Notes: Estimates of the yield to maturity of the CoCos issued by European banks, } \\
\text { excluding DB. Random-effect GLS estimation with clustered standard errors by } \\
\text { "bank*time" and intragroup correlation is shown in column } 1 \text {; feasible GLS esti- } \\
\text { mation with heteroskedastic error structure across panels and panel-specific AR(1) } \\
\text { process within panels is reported in column } 2 \text {; Blundell-Bond system GMM estimate } \\
\text { is shown in column } 3 \text {. For the GMM, Hansen, AR(1), and AR(2) tests are provided. } \\
\text { Robust standard errors are in parentheses. }{ }^{* * *} p<0.01,{ }^{* *} p<0.05,{ }^{*} p<0.1 \text {. }\end{array}$} \\
\hline
\end{tabular}

by the significant coefficients of both variables Stock $_{j, t}$ Dummy $y_{s, t}$ (columns 2 and 3) and $E D F_{j, t} D_{u m m} y_{s, t}$ (columns 1, 2, and 3).

\subsection{Omitted Variables}

In two out of the three estimations presented in table 6 , the DB CoCo variable is not a significant driver of other banks' CoCo YTM under normal market conditions, as we expected. However, in the estimation (column 2) it turned out to be significant. Even though it is so only in one out of three estimations, we suspect that its significance might be due to a possible omitted-variable problem, which 
is to say that omitted or unobservable variables might drive both DB's and other banks' CoCos YTM, hence the significance of the DB's CoCos in table 6.

In order to test for this possibility, we perform a four-step procedure which aims to separate the effect of any omitted variable from any DB-specific effect. The procedure is the following. First, we run a principal component analysis (PCA) on the data set of CoCos YTM, which includes both the CoCos issued by $\mathrm{DB}$ and those issued by the other banks. By means of the PCA, we aim to identify those components that capture the CoCos co-movements. As such, they should also reflect the effect of any unobserved variable that affect all CoCos similarly. Second, we select the components that together explain a significant proportion of the overall variance of our CoCos data set; in particular, we consider the first four components that together account for about 87 percent of the variance. Third, we use them as regressors to explain the DB's CoCos YTM; the resulting residuals are stored, as they constitute the "purely" idiosyncratic part of the DB's CoCos YTM which remains unexplained from the regression. Fourth, with an approach similar in spirit to the forecasting method proposed by Stock and Watson (2002), we study the CoCo YTM running again the FGLS estimate of equation (1), but instead of including the DB CoCo YTM and its interactions with the two stress events, we use as regressors (i) the first four principal components selected in the previous step; and (ii) the stored DB-specific residuals, which we also interact with the two DB stress events. Following this procedure, we should be able to isolate any true DB-specific effect from that of any omitted or unobservable variable.

The results of the FGLS regression, which are comparable to those presented in table 6 , column 2 , are shown in table 13 . They confirm our hypothesis that the significance of the CoCo DB variable evidenced in table 6 , column 2 is more likely to be due to an omittedvariable problem rather than to a DB-specific role in explaining other banks' CoCos YTM in normal times. In fact, the results show that the DB-specific variable (DB residuals) is not significant once we control for possible omitted variables with the first four principal components (all significant). These results also strengthen our argument about the existence of a CoCo-specific contagion channel from DB to other banks during the first stress event, as the interaction of 
Table 13. Controlling for Omitted Variables

\begin{tabular}{|c|c|}
\hline Variables & FGLS \\
\hline Lag CoCo YTM & $\begin{array}{c}0.997^{* * *} \\
(0.001)\end{array}$ \\
\hline Senior Bond YTM & $\begin{array}{c}0.064^{* * *} \\
(0.023)\end{array}$ \\
\hline Stock Return & $\begin{array}{c}-0.096^{* * *} \\
(0.003)\end{array}$ \\
\hline EDF Change & $\begin{array}{c}0.813^{* * *} \\
(0.150)\end{array}$ \\
\hline Distance to Trigger & $\begin{array}{c}-0.010^{* *} \\
(0.004)\end{array}$ \\
\hline Component 1 & $\begin{array}{c}0.000^{* * *} \\
(0.000)\end{array}$ \\
\hline Component 2 & $\begin{array}{c}0.000^{* * *} \\
(0.000)\end{array}$ \\
\hline Component 3 & $\begin{array}{c}-0.001^{* * *} \\
(0.000)\end{array}$ \\
\hline Component 4 & $\begin{array}{c}0.000^{* * *} \\
(0.000)\end{array}$ \\
\hline DB Residuals & $\begin{array}{l}-0.071 \\
(0.098)\end{array}$ \\
\hline Event1 & $\begin{array}{c}-0.004^{* * *} \\
(0.000)\end{array}$ \\
\hline Event2 & $\begin{array}{c}0.000 \\
(0.000)\end{array}$ \\
\hline DB Residuals $\times$ Event1 & $\begin{array}{c}4.767^{* * *} \\
(0.157)\end{array}$ \\
\hline DB Residuals $\times$ Event2 & $\begin{array}{l}-0.302 \\
(0.197)\end{array}$ \\
\hline CoCos Characteristics: & \\
\hline Subordination Type & $\begin{array}{c}-0.001^{* *} \\
(0.000)\end{array}$ \\
\hline Equity Conversion & $\begin{array}{c}0.000 \\
(0.000)\end{array}$ \\
\hline Permanent Write-Down & $\begin{array}{c}0.001 \\
(0.000)\end{array}$ \\
\hline Cancellation by Regulators & $\begin{array}{l}-0.000^{*} \\
(0.000)\end{array}$ \\
\hline
\end{tabular}




\section{Table 13. (Continued)}

\begin{tabular}{|l|c|}
\hline Variables & FGLS \\
\hline Trigger Level & 0.000 \\
Size & $(0.000)$ \\
& -0.000 \\
Constant & $(0.000)$ \\
& $-0.008^{* * *}$ \\
Observations & $(0.001)$ \\
Number of ISIN & 17,788 \\
& 80 \\
Notes: Feasible GLS estimation of the yield to maturity of the CoCos issued by Euro- \\
pean banks, excluding DB. The estimation allows for heteroskedastic error structure \\
across panels and a panel-specific AR(1) process within panels. Robust standard \\
errors are in parentheses. ${ }^{* * *} p<0.01, * * p<0.05, * x<0.1$. \\
\hline
\end{tabular}

the DB residuals variable with the first stress-event dummy is very significant.

\section{Conclusions and Policy Implications}

Our empirical analysis provides evidence of, on the one hand, the existence of a CoCo-specific contagion channel in the propagation of the distress of DB to the rest of the European banks in the first stress episode considered and, on the other hand, the fact that such a contagion channel seems to have waned in the second episode.

From a financial stability perspective, the widespread turbulence in the CoCos market during an idiosyncratic shock is not totally explained by fundamentals and supports the idea of CoCo skeptics that these instruments might prove destabilizing. In fact, in the aftermath of the January-February turmoil, some senior bank executives complained that the rules for CoCos are too complicated and could undermine a bank's financial position rather than strengthen it in a crisis (Arnold and Hale 2016). Concerns regarding these instruments were compounded by the uncertainties surrounding the interaction between the results of the EU-wide stress test and the pillar 2 requirement, together with the direct consequences of this interaction on the level of the MDA trigger point, i.e., the capital level 
below which a bank faces restrictions on the amount of distributable profits, including in the form of coupon payments on CoCos.

The ECB (2016b) clarified its position on July 29, 2016, in apparent coordination with the simultaneous publication of the stresstest results by the EBA (2016a) 23 In particular, the ECB not only reduced uncertainty on the supervisory framework in a dimension that is crucial for investors to understand the repayment behavior of CoCos, but also de facto increased the protection of CoCos' investors by making it less likely that banks would face restrictions on the payment of coupons on AT1 instruments 24

Both the reduction in uncertainty and the enhancement of protection are likely to have played a role in the eliminating the CoCospecific contagion in the second DB stress period identified in our empirical analysis. In addition to that, the absence of Coco-specific contagion in the second DB stress period could also result from a "learning process" from investors that made agents more aware of the riskiness of these instruments at the time of the second stress event, thereby rendering CoCos' prices less volatile during idiosyncratic shocks. More market stability in stressed periods is certainly reassuring regarding the convenience of CoCos as a substitute of costlier common equity for the purpose of increasing banks' lossabsorption capacity.

We conclude the paper with a final comment. One of the most appraised features of $\mathrm{CoCos}$ is that of enabling the recapitalization of an institution as a going concern, that is, ahead of resolution. This property distinguishes CoCos from other AT2 instruments such as subordinated debt or bail-in eligible liabilities (Minimum Requirement for own funds and Eligible Liabilities, MREL) that allow for the bank recapitalization as a gone concern, that is, in a resolution

\footnotetext{
${ }^{23}$ It announced that one element of the quantitative results of the stress test (that is the potential capital shortfall under adverse scenario) would be an input of the nonbinding pillar 2 guidance, a newly introduced element of the Supervisory Review and Evaluation Process (SREP) that, as opposed to pillar 2 requirements, does not contribute to the determination of the MDA trigger.

${ }^{24}$ In the European Central Bank's (2016a) own words, with "the introduction of the component of Pillar 2 guidance, the capital requirements of a bank in terms of Pillar 1 plus Pillar 2 requirements will be reduced - all things being equal. As a result, the trigger for the maximum distributable amount (MDA) will go down - also all things being equal."
} 
process. Yet, the supervisory actions described above went in the direction of relaxing the conditions that may lead to automatic restrictions on the payment of CoCos' coupons, thereby reducing the ability of these liabilities to provide for additional capital as a going concern, and rendering them de facto closer to AT2 instruments. While the ECB actions might have been justified (and the need for a reduction on uncertainty on supervisory treatment was uncontroversial), neither supervisory authorities nor investors should interpret them as an implicit recognition that "whatever it takes" will be done to stabilize CoCos markets. These instruments will only be useful if they achieve in practice what they are supposed to do by their design, namely the recapitalization of an institution as a going concern in a smooth manner that disrupts neither the institution itself nor the rest of the system.

\section{References}

Admati, A. R., P. M. DeMarzo, M. F. Hellwig, and P. C. Pfleiderer. 2013. "Fallacies, Irrelevant Facts, and Myths in the Discussion of Capital Regulation: Why Bank Equity is Not Socially Expensive." Paper No. 2013/23, Max Planck Institute for Research on Collective Goods.

Allen, H. J. 2012. "Cocos Can Drive Markets Cuckoo." Lewis \& Clark Law Review 16: 125.

Arnold, M., and T. Hale. 2016. "ECB Is Having Second Thoughts on 'Coco' Bonds." Financial Times, April 24.

Avdjiev, S., B. Bogdanova, P. Bolton, W. Jiang, and A. Kartasheva. 2020. "CoCo Issuance and Bank Fragility." Forthcoming in Journal of Financial Economics. https://www.sciencedirect. com/science/journal/aip/0304405X] or https://doi.org/10.1016/ j.jfineco.2020.06.008

Avdjiev, S., A. V. Kartasheva, and B. Bogdanova. 2013. "CoCos: A Primer." BIS Quarterly Review (September): 43-56.

Basel Committee for Banking Supervision. 2011a. "Basel III: A Global Regulatory Framework for More Resilient Banks and Banking Systems - Revised Version June 2011." Bank for International Settlements. 
. 2011b. "Basel III Definition of Capital - Frequently Asked Questions - December 2011." Bank for International Settlements.

Bekaert, G., M. Ehrmann, M. Fratzscher, and A. Mehl. 2014. "The Global Crisis and Equity Market Contagion." Journal of Finance 69 (6): 2597-2649.

Bekaert, G., C. R. Harvey, and A. Ng. 2005. "Market Integration and Contagion." Journal of Business 78 (1): 39-69.

Berg, T., and C. Kaserer. 2015. "Does Contingent Capital Induce Excessive Risk-taking?" Journal of Financial Intermediation 24 (3): $356-85$.

Blundell, R., and S. Bond. 1998. "Initial Conditions and Moment Restrictions in Dynamic Panel Data Models." Journal of Econometrics 87 (1): 115-43.

Brigo, D., J. Garcia, and N. Pede. 2015. "Coco Bonds Pricing with Credit and Equity Calibrated First-Passage Firm Value Models." International Journal of Theoretical and Applied Finance 18 (3): $1-31$.

Calomiris, C. W., and R. J. Herring. 2013. "How to Design a Contingent Convertible Debt Requirement that Helps Solve our TooBig-to-Fail Problem." Journal of Applied Corporate Finance 25 (2): 39-62.

Calvo, G. A., and E. G. Mendoza. 2000. "Rational Contagion and the Globalization of Securities Markets." Journal of International Economics 51 (1): 79-113.

Claessens, S., R. Dornbusch, and Y. C. Park. 2001. "Contagion: Why Crises Spread and How This Can Be Stopped." In International Financial Contagion, ed. S. Claessens and K. Forbes, 19-41. Springer.

Davies, P. J. 2016. "Deutsche Bank to be Hurt by Mortgage Penalty." The Wall Street Journal, September 19.

Delivorias, A. 2016. "Contingent Convertible Securities: Is a Storm Brewing?" Briefing, European Parliamentary Research Service.

Donahue, P. 2016. "Merkel Rules Out Assistance for Deutsche Bank." September 24. http://www.bloomberg.com/news/ articles/2016-09-24/merkel-rules-out-assistance-for-deutschebank-focus-reports.

Drukker, D. M. 2003. "Testing for Serial Correlation in Linear PanelData Models." Stata Journal 3 (2): 168-77. 
Duffie, D. 2009. "Contractual Methods for Out-of-Court Restructuring of Systemically Important Financial Institutions." Submission requested by the U.S. Treasury Working Group on Bank Capital, draft of November 9.

European Banking Authority. 2015. "Opinion of the European Banking Authority on the Interaction of Pillar 1, Pillar 2 and Combined Buffer Requirements and Restrictions on Distributions."

- 2016a. "2016 EU-wide Stress Test Results."

- 2016b. "EBA Clarifies Use of 2016 EU-wide Stress Test Results in the SREP Process." Press Release (July 1).

European Central Bank. 2016a. "Frequently Asked Questions on the 2016 EU-wide Stress Test."

\section{6b. SSM SREP Methodology Booklet - 2015 Edition.}

Federal Reserve Board. 2016. "Comprehensive Capital Analysis and Review 2016: Assessment Framework and Results."

Flannery, M. J. 2005. No Pain, No Gain? Effecting Market Discipline via "Reverse Convertible Debentures." Capital Adequacy beyond Basel: Banking, Securities, and Insurance, ed. H. S. Scott, 171-196. Oxford University Press.

. 2016. "Stabilizing Large Financial Institutions with Contingent Capital Certificates." Quarterly Journal of Finance 6 (2): $1-26$.

Forbes, K. J. 2012. "The 'Big C': Identifying Contagion." Technical Report, National Bureau of Economic Research.

Forbes, K. J., and R. Rigobon. 2002. "No Contagion, Only Interdependence: Measuring Stock Market Comovements." Journal of Finance 57 (5): 2223-61.

Glasserman, P., and B. Nouri. 2012. "Contingent Capital with a Capital-Ratio Trigger." Management Science 58 (10): 1816-33.

Glover, J. 2016. "Deutsche Bank Coco Bonds Have Bumpy Ride as Lender Struggles." January 28. http://www.bloomberg.com/ news/articles/2016-01-28/deutsche-bank-coco-investors-havebumpy-ride-as-lender-struggles,

Goncharenko, R., S. Ongena, and A. Rauf. 2020. "The Agency of CoCos: Why Contingent Convertible Bonds Are Not for Everyone." Forthcoming in Journal of Financial Intermediation. https://doi.org/10.1016/j.jfi.2020.100882.

Goodhart, C. 2010. "Are Cocos from Cloud Cuckoo-land?" Central Banking 21: 29-33. 
Hilscher, J., and A. Raviv. 2014. "Bank Stability and Market Discipline: The Effect of Contingent Capital on Risk Taking and Default Probability." Journal of Corporate Finance 29 (December): $542-60$.

International Monetary Fund. 2016. "Germany Financial Sector Assessment Program." IMF Country Report No. 16/191 (October).

Maddala, G. S., and S. Wu. 1999. "A Comparative Study of Unit Root Tests with Panel Data and a New Simple Test." Oxford Bulletin of Economics and Statistics 61 (S1): 631-52.

Martynova, N., and E. Perotti. 2018. "Convertible Bonds and Bank Risk-taking." Journal of Financial Intermediation 35 (Part B): 61-80. https://doi.org/10.1016/j.jfi.2018.01.002.

Pazarbasioglu, C., M. J. P. Zhou, V. Le Leslé, and M. Moore. 2011. "Contingent Capital: Economic Rationale and Design Features." IMF Staff Discussion Note No. 11/01.

Pennacchi, G. 2011. "A Structural Model of Contingent Bank Capital." Working Paper No. 10-04, Federal Reserve Bank of Cleveland.

Pennacchi, G., T. Vermaelen, and C. C. Wolff. 2014. "Contingent Capital: The Case of COERCs." Journal of Financial and Quantitative Analysis 49 (3): 541-74.

Pericoli, M., and M. Sbracia. 2003. "A Primer on Financial Contagion." Journal of Economic Surveys 17 (4): 571-608.

Posner, K. A. 2010. "Thoughts on The Squam Lake Report: Reengineering the Financial System to Better Withstand Extreme Volatility." Journal of Applied Corporate Finance 22 (3): 34-39. Squam Lake Working Group on Financial Regulation. 2009. "An Expedited Resolution Mechanism for Distressed Financial Firms: Regulatory Hybrid Securities." Working Paper No. 10, Council on Foreign Relations.

Stock, J. H., and M. W. Watson. 2002. "Macroeconomic Forecasting Using Diffusion Indexes." Journal of Business and Economic Statistics 20 (2): 147-62.

Strasburg, J. 2016. "Deutsche Faces Plight of Capital in U.S. Litigation." The Wall Street Journal, September 19.

Sundaresan, S., and Z. Wang. 2015. "On the Design of Contingent Capital with a Market Trigger." Journal of Finance 70 (2): 881-920. 
Vallee, B. 2019. "Contingent Capital Trigger Effects: Evidence from Liability Management Exercises." Review of Corporate Finance Studies 8 (2): 235-59.

Wilkens, S., and N. Bethke. 2014. "Contingent Convertible (CoCo) Bonds: A First Empirical Assessment of Selected Pricing Models." Financial Analysts Journal 70 (2): 59-77.

Wooldridge, J. M. 2002. Econometric Analysis of Cross Section and Panel Data. The MIT Press. 